\title{
Foreign Direct Investment Outflows : Asian Developing Countries
}

\author{
Sayeeda Bano \\ The University of Waikato, Hamilton, New Zealand \\ Jose Tabbada \\ Institute for Strategic and Development Studies, Quezon City, The Philippines
}

\begin{abstract}
Foreign Direct Investment originating from East, Southeast, and South Asian developing countries has increased significantly since 1980. This paper examines the extent and determinants of Foreign Direct Investment outflows from these countries between 1980 and 2011. We use selected home country-specific macroeconomic variables and identifies the key determinants of Foreign Direct Investment outflows using correlation and regression analysis. The results show that Foreign Direct Investment outflows are closely associated with high levels of Gross Domestic Product, high domestic savings, large foreign reserves, export orientation, and relatively large Foreign Direct Investment inflows in the source countries, with the strength and importance of each factor varying with the level of development. Our main conclusion is that, although non-traditional
\end{abstract}

\footnotetext{
* Corresponding Author: Sayeeda Bano ; Department of Economics, The University of Waikato, Hamilton, New Zealand; Tel: +64 78384931, Fax:+64 78384331, E-mail: sbano@waikato.ac.nz.

Co-Author: Jose Tabbada; Institute for Strategic and Development Studies, Diliman, Quezon City, The Philippines; Tel: +63 29311022, E-mail: josetabbada@hotmail.com.

Acknowledgements: The authors express their sincere thanks to the Department of Economics, University of Waikato. Our sincere thanks to Brian Silverstone for his valuable comments. Thanks and appreciation is also due to Suhail Farhad, Haseeb Bhatti, Neilita Tabbada and Dong Zhigang for their research assistance. An early version of this paper was presented at the 2012 Euro-Asia Management Studies Association (EAMSA) Conference held at the National University of Singapore. Our thanks are also due to conference delegates, Maria Fitzgerald, the anonymous referee and the journal editor for their valuable comments. Any remaining errors and omissions are entirely our own.
} 
Foreign Direct Investment outflows have so far been confined to a limited number of developing countries, mostly Asian, other developing countries could also become capital exporters with a supportive international environment and appropriate domestic policies.

JEL Classifications: F21, F43, F41

Keywords: Foreign Direct Investment, Developed Countries, Developing Countries, East Asia, Southeast Asia, South Asia

\section{Introduction}

It was once assumed that Foreign Direct Investment (FDI) naturally flows from more industrialized to less-industrialized countries, or from capital-rich to capital-scarce developing countries. In recent decades, however, a new phenomenon has appeared, namely, a reverse flow of FDI (henceforth reverse FDI) from the developing to the developed and to other developing countries. This phenomenon is a continuation of the process of globalization that has been going on since the second half of the $19^{\text {th }}$ century, interrupted only briefly by World Wars I and II and the Great Depression of the 1930s. ${ }^{1}$

The majority of FDI still originates from developed countries and goes to other developed countries (UNCTAD 2012) but during the past couple of decades, reverse FDI has become substantial and significant enough to attract the attention of researchers. In 2008, for example, there were 21,000 multinational enterprises from developing countries and nearly 2,000 from transition economies. Of the former, 3,500 were from China, 1,000 from Russia, 815 from India, and 220 from Brazil (Sauvant et al. 2009).

Reverse FDI is not an entirely new phenomena. It may have started with Japan during the 1960s and 1970s, barely two decades after the country's industrial base was reduced to rubble during World War II. Japan was the first Asian country to experience modern industrialization as well as rapid and sustained economic growth. Japanese investment flowed in successive waves - first to the so-called Asian tigers or dragons

\footnotetext{
${ }^{1}$ While most writers consider globalization to be a late $20^{\text {th }}$ century phenomenon, the more history-conscious ones are aware that it has been going on for most of the $20^{\text {th }}$ century, and may actually go as far back as the second half of the $19^{\text {th }}$ century under various other names such as internationalization and imperialism. What differentiates the current phase of globalization from earlier ones is the speed of transport, communications and financial transactions, the latter two due largely to the revolution in information and communication technologies.
} 
consisting of Hong Kong, South Korea, Taiwan, and Singapore, then to other rapidlyindustrializing Southeast Asian countries (Malaysia, Indonesia, and Thailand) and next to North America, particularly the US, and the European Union (EU). Japan's overseas expansion was replicated during the 1980s 1990s by the Asian tigers. Now, other rapidly-industrializing countries, China, India, Indonesia, Malaysia, and Thailand have also joined the line. By the sheer size of their populations and domestic economies, China and India will alter the world's investment profile. Already, Indian multinationals such as Tata and Wipro and Chinese firms such as Huawei and Lenovo are becoming household names in host countries. A sample of multinational corporations from the selected developing countries is shown in Table 1. 


\section{Table 1. Multinationals from developing countries}

\begin{tabular}{|c|c|c|c|c|}
\hline Name of Firm & Nationality & $\begin{array}{l}\text { Total Assets } \\
\text { (in billion US } \\
\text { dollar, 2013) } \\
\end{array}$ & $\begin{array}{c}\text { Number of } \\
\text { countries where } \\
\text { firm operates }\end{array}$ & Products or Services \\
\hline Tata Group $^{2}$ & India & 107.17 & $100+$ & $\begin{array}{l}\text { Steel, motors, power, chemicals, } \\
\text { beverages, tele services, hotels, } \\
\text { communications, consultancy } \\
\text { services }\end{array}$ \\
\hline Wipro $^{3}$ & India & 6.9 & 60 & $\begin{array}{l}\text { Information technology, } \\
\text { consulting and outsourcing } \\
\text { services }\end{array}$ \\
\hline $\mathrm{CEMEX}^{4}$ & Mexico & 38.02 & $50+$ & $\begin{array}{l}\text { Cement, aggregates, } \\
\text { ready-mixed cement, related } \\
\text { products and services. }\end{array}$ \\
\hline $\begin{array}{l}\text { Zhejang Geely } \\
\text { Holding Grp }\end{array}$ & China & 16.05 & 2 & $\begin{array}{l}\text { Automobile, motorcycle, } \\
\text { power train }\end{array}$ \\
\hline Huawei $^{6}$ & China & 39.463 & $100+$ & $\begin{array}{l}\text { Telecommunications } \\
\text { equipment and services }\end{array}$ \\
\hline Lenovo $^{7}$ & China & 34 & $60+$ & $\begin{array}{l}\text { Personal technology, PCs and } \\
\text { mobile internet devices }\end{array}$ \\
\hline $\begin{array}{l}\text { San Miguel } \\
\text { Corporation }^{8}\end{array}$ & Philippines & 26.68 & 7 & $\begin{array}{l}\text { Beverages, food packaging, fuel } \\
\text { and oil, mining, infrastructure, } \\
\text { aviation, telecommunications }\end{array}$ \\
\hline Genting Group $^{9}$ & Malaysia & 21.81 & 2 & $\begin{array}{l}\text { Leisure and hospitality, power } \\
\text { generation, oil palm plantation, } \\
\text { oil and gas }\end{array}$ \\
\hline $\begin{array}{l}\text { Thai Union } \\
\text { Frozen Products } \\
\text { Public Co. }\end{array}$ & Thailand & 3.34 & 5 & $\begin{array}{l}\text { Frozen and canned sea foods, } \\
\text { packing products, animal feeds, } \\
\text { aquaculture }\end{array}$ \\
\hline Salim Group $^{11}$ & Indonesia & $\begin{array}{l}20.0 \\
(1997)\end{array}$ & 8 & $\begin{array}{l}\text { Instant noodles, palm oil, flour } \\
\text { milling, golf course, logging, } \\
\text { hotel and resort, property } \\
\text { development }\end{array}$ \\
\hline Viettel Group $^{12}$ & Vietnam & $\begin{array}{c}7.0 \\
\text { (Total Revenue) }\end{array}$ & 5 & $\begin{array}{l}\text { Mobile networks, } \\
\text { telecommunication services }\end{array}$ \\
\hline
\end{tabular}

\footnotetext{
${ }^{2}$ Founded in 1868 , the Tata group is a global enterprise and comprises over 100 operating companies in seven business sectors: communications and information technology, engineering, materials, services, energy, consumer products and chemicals (Tata 2014).

${ }^{3}$ Wipro Ltd (NYSE:WIT) is a global information technology, consulting and outsourcing company with 145,000 employees serving over 900 clients in 60 countries (Wipro Ltd 2014).

${ }^{4}$ CEMEX is a global building materials company that produces, distributes, and sells cement, ready-mix concrete and aggregates throughout the Americas, Europe, Africa, the Middle East and Asia (CEMEX S.A.B. 2014).
} 
Being a new phenomenon, reverse FDI has raised concerns in host countries, most of which have previously been home rather than host to FDI. For example, the Chinese car firm Geely's acquisition of Volvo aroused some negative reactions in Sweden, the host country. The Philippines-based San Miguel Corporation's acquisition of controlling shares in Australia's National Foods, outbidding its nearest rival New Zealand's food and dairy conglomerate Fonterra, met a more or less similar reception in Australia. It is not just the host countries that regard FDI with some concern, if not outright hostility. In the home countries, there has also been concern, especially during economic slowdowns, about job loss to host countries.

During the 1980s, Japanese FDI in the US entertainment, real estate, car and other industries aroused intense reactions in the host country. Terms that evoked fear like second Japanese invasion and yellow peril became popular in the US media. Similarly, when US corporations were spreading rapidly across Europe and elsewhere in the 1960s and 1970s, concerns over an American invasion were also raised in the host countries. To meet this American Challenge, European corporations with the active support of their respective governments, went through a period of consolidation and rationalization in order to be competitive.

This study is not about host country reactions to FDI, whether positive or negative, nor the impact of FDI. Rather, it is about the origin, magnitude and determinants of FDI from developing countries. Specifically, this paper aims to:

\footnotetext{
${ }^{5}$ Zhejiang Geely Holding Group Co., Ltd. manufactures automobiles in China, was founded in 1986 and is based in Hangzhou, China with manufacturing bases in Linhai, Ningbo, Luqiao, Shanghai, Lanzhou, Xiangtan, Jinan and Chengdu, China; it has a manufacturing factory as well as a research and development center in Australia (Business Week 2014).

${ }^{6}$ Huawei Technologies Co. Ltd. is the largest telecommunications equipment maker in the world, having overtaken Ericsson in 2012 (Huawei Technologies Co. 2014).

${ }^{7}$ Lenovo Group Ltd. is a Chinese multinational computer technology company that designs, develops, manufactures and sells personal computers, tablet computers, smart phones, workstations, servers, electronic storage devices, IT management software and smart televisions (Lenovo 2013).

${ }^{8}$ Established in 1890 as a brewery, San Miguel Corporation (PSE: SMC) is Southeast Asia's largest publicly listed food, beverage and packaging company (San Miguel Corporation, 2014).

${ }^{9}$ Genting Group is a Malaysian conglomerate comprising four listed entities: Genting Berhad and its member companies Genting Malaysia Berhad, Genting Plantations Berhad, Genting Singapore Plc and Genting Hong Kong Limited (Genting Group 2014).

${ }^{10}$ TUF's long history of frozen seafood processing and export started in 1988 when it embarked on a joint venture with Mitsubishi Corporation and Hagoromo Foods Corporations (Thai Union Frozen Products PCL. by Thai Union Group 2012).

${ }^{11}$ The Salim Group is Indonesia's biggest conglomerate with assets including Indofood Sukses Makmur, the world's largest instant noodle producer, and Bogasari, a large flour-milling operation. It also owns major oil palm plantations (about 1,000 $\mathrm{km}^{2}$ ) and logging concessions (Salim Group 2014).

${ }^{12}$ Viettel Group is Vietnam's largest mobile network operator. It is a state-owned enterprise wholly owned and operated by the Ministry of Defence. Viettel pays its 25,000 employees an average salary of 18 million VND per month, a total of 5.4 trillion VND per year (Viettel Group 2011).
} 
(i) Describe outward FDI from developing countries: their major country sources, magnitude, growth and related characteristics;

(ii) Discern current and emerging trends and patterns in FDI inflows and outflows;

(iii) Identify the principal determinants of outward FDI from developing countries; and

(iv) Determine the extent to which these factors explain the outward flow of FDI from the home countries.

The paper is organized into six sections. Section II review recent literature on the determinants of outward FDI from developing countries. Section III presents data, statistics, and figures describing the growing magnitude and significance of reverse FDI, identifying the major trends and patterns. Section IV outlines hypotheses for the observations made in the previous section, particularly regarding outward FDI. Section $\mathrm{V}$ tests the hypothesized relationships and analyses the results, while the final section presents our conclusions and policy implications.

\section{Literature Review}

What drives outward FDI in developing countries? More specifically, what are the home-country determinants of outward FDI? Why are some developing countries sources of more outward investment than others?

There has been a resurgence of reports and studies on FDI following a diminished interest in the 1980s and 1990s. These studies include comprehensive reports such as United Nations Conference on Trade and Development's (UNCTAD) World Investment Report and Global Investment Trends Monitor, which track annual investment flows and other developments, and more narrowly focused journal papers and articles. These studies provide a description of FDI such as its growth and magnitude, its source or origin (home country) and destination (host country), its mode of entry - as greenfield investment (i.e., investment in new production facilities) or as through mergers and acquisitions, whether as direct investment or as portfolio investment and which industries or sectors (agriculture, manufacturing or services) are the recipients of FDI. Some studies point to the growing role of sovereign wealth funds and state-owned enterprises as alternative sources of foreign investment. 
Most studies on the determinants of FDI have focused on the pull factors, or features of the host countries that attract or deter FDI inflows. Foreign investment in general is not attracted to poor countries, except as sources of cheap labor and raw materials; thus, there has been a proliferation of policy-oriented studies seeking to make a particular country's investment climate more attractive to foreign and local investors by, for example, maintaining macroeconomic stability, upgrading a country's infrastructure and human resources and improving governance by minimizing corruption and reducing red-tape in government. Although this study is about the push factors, a brief review of some of the studies dealing with the pull factors is useful for understanding the whole phenomena of outward FDI.

A study of Chinese outward FDI by Buckley et al. (2007) examined pull factors such as the host country's market size, rate of growth, natural resource endowments, ownership advantages, political risk, cultural proximity, inflation and openness to FDI. The authors also examined push factors, such as China's outward FDI liberalization policy, the distance between home and host country and export orientedness. Their findings are that market size (measured by GDP), cultural proximity (measured by the size of the Chinese diaspora in the host country), FDI policy liberalization and export orientedness had a significant and positive effect on Chinese outward FDI. They also noted that state-owned enterprises accounted for a substantial proportion of China's outward FDI and that the Chinese government played a very important role in encouraging outward FDI. Overall, the authors note that China's outward FDI has both a conventional and an idiosyncratic dimension.

Kolstad and Wiig (2012) confirm some of Buckley et al.'s findings that Chinese FDI outflows are attracted to countries with large internal markets and abundant natural resources and that countries with poor institutions of governance attracted Chinese FDI, especially when combined with abundant natural resources. Cheng and Ma (2007), like Buckley et al. found that between 2003 and 2006, GDP and cultural bonding had a positive effect on Chinese outward FDI in 90 host countries while geographical distance had a negative effect. Cheung and Qian's (2009) examination of Chinese outward FDIs in 31 host countries during 1991 2005 confirmed that natural resources and a country's GDP are significant factors in attracting Chinese FDI; however, GDP per capita had the opposite effect.

The foregoing studies focused on the pull factors. Banga (2008) provides one of the most comprehensive analyses of home-country determinants or drivers of FDI from developing countries, classifying these into capability-related drivers, domestic drivers 
and trade-related drivers. Capability-related drivers are the necessary skills, technology, information and capital which are required to undertake outward FDI. Inward FDI flows are an important capability driver because they transfer technology to the host country as well as the necessary FDI managerial skills. Domestic drivers, on the other hand, are the constraints on domestic firms, such as poor infrastructure, high cost of capital and labour and the limited size of the domestic market, that compel a country's firms to establish production facilities in other countries in order to escape these domestic constraints. Finally, foreign trade is an important FDI driver. According to the product life-cycle theory, outward FDI is a logical next step taken by a firm whose initial business is exporting to the (prospective) host country, thereby gaining familiarity with foreign markets.

Using regression analysis, Banga (2008) showed that most exports-to-GDP and imports-to-GDP are significant trade-related drivers of outward FDI, as are previous FDI inflows to the home country. Poor infrastructure and high real wages, but not the small size of the domestic market, are also important determinants of outward FDI.

Kayam (2009), following UNCTAD (2006), uses home-market conditions, trade conditions, domestic costs of production, local business conditions and home government policies as the home-country drivers of outward FDI. Kayam's principal hypothesis is that outward FDI increases with foreign competition coming from inward FDI in the domestic market. This happens because inward FDI crowds out domestic investment, forcing domestic entrepreneurs to seek investment opportunities abroad. As government stability, bureaucratic quality and the investment profile of the home country improve, outflows of capital decrease.

Using cointegration tests, Masron and Shahbudin (2010) examine the determinants of outward FDI from Malaysia and Thailand. The domestic cost of production, domestic market and business competition and the liberalization of the capital markets are identified as very important factors driving outward FDI from these countries, but their small sample size limits the generality of the authors' findings and conclusions.

Tolentino (2010) uses vector autoregression to examine the effect on Chinese and Indian outward FDIs of selected home-country macroeconomic variables: openness of the economy, interest rates and exchange rates. The author hypothesizes that lower interest rates (capital abundance) lead to higher capital outflows. On the other hand, an appreciation of the home-country's exchange rate, "by lowering the capital requirment of outward FDI in domestic currency units and reducing the competitiveness of exports, encourages outward FDI" (p.104). The author nevertheless concludes that increasing 
global integration eventually diminishes the role of home country-specific national factors and suggests that other explanatory variables should also be considered.

Using six case studies from China, India and South Africa, all with substantial outward FDI, Baskaran et al. (2011) found that the motivations of outward FDI are the same as those that drive developed-country multinational corporations to invest in other countries: to move up the value chain, to secure raw materials and to gain access to markets, technology and other sources of competitive advantage in the host countries.

\section{FDI Flows and Stocks}

This section presents evidence on FDI inflows and outflows as well as FDI stocks in order to provide a comprehensive view of the investment situation in the world. The compiled time series data on FDI inflows and outflows are reported in Tables 3 and 4 of the Appendices. This data is also shown by Figures 1, 2, and 3 for developing countries and Figures 4 and 5 for developed countries. Also, the shares of FDI of selected countries are shown in Figures 6 and 7 for comparison.

\section{A. Overall trends and patterns}

Developing-country inflows and outflows were on an upward trend during 1980 2011, with FDI inflows increasing almost 100-fold from 7 billion US dollars in 1980 to 684 billion dollars in 2011 and with FDI outflows increasing 128-fold from 3 billion dollars to 384 billion dollars. Both inflows and outflows track each other throughout the period, with the inflows higher than the outflows, at least since 1990. Inflows peaked in 2000 and 2008 while outflows peaked in 2000 and 2010, with the later peak being very much higher in comparison as shown in Figure 1. Note that the inflows peaked at the start of the recession in 2008, while outflows peaked two years after the start of the recession. 


\section{Figure 1. Foreign direct investment flows in developing economies}

(Measurement Unit: Billion US dollars)

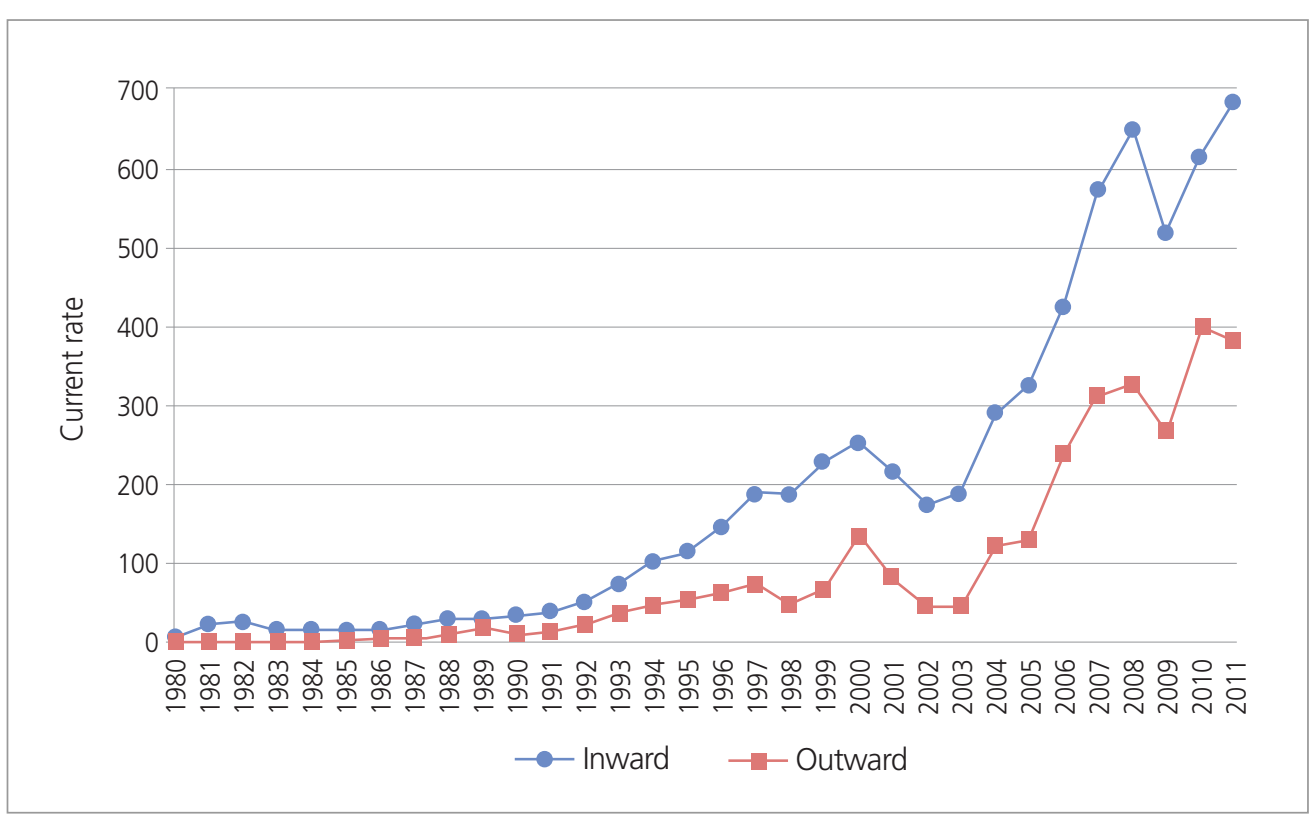

(Source) UNCTAD Statistics (2012).

A cautionary note on the source of some FDI flows is necessary. Recent years have seen the increasing role of indirect FDI, so-called because the investor's immediate country of origin may not necessarily reflect the investor's true nationality. For example, investment recorded as originating from Hong Kong (and therefore listed as of Chinese or Hong Kong origin) may actually be that of an Indonesian-owned multinational whose headquarters is in Hong Kong. Investments from tax havens, such as the Bahamas and certain other territories in the Caribbean, and from countries where holding companies are based, such as Luxembourg, are other examples. The effect of indirect investment is to overstate the amount of investment from these small countries, administrative regions or entities. Knowing which countries are tax havens or headquarter sites should alert the reader to be careful when interpreting abnormally high levels of FDI coming from these locations.

As a result of the increased developing-country flows, the share of developing countries of world FDI inflows and outflows has been on an upward trend, with inflows doubling the outflows both at the beginning (1980) and at the end of the period (2011). The share of developing countries in FDI inflows peaked in 2010, with lower peaks in 
1982, 1994 and 2004. FDI outflows from developing countries followed a smoother, and generally upward, trend as shown in Figure 2.

\section{Figure 2. The weight of FDI in developing economies}

(as percentage of world direct investment)

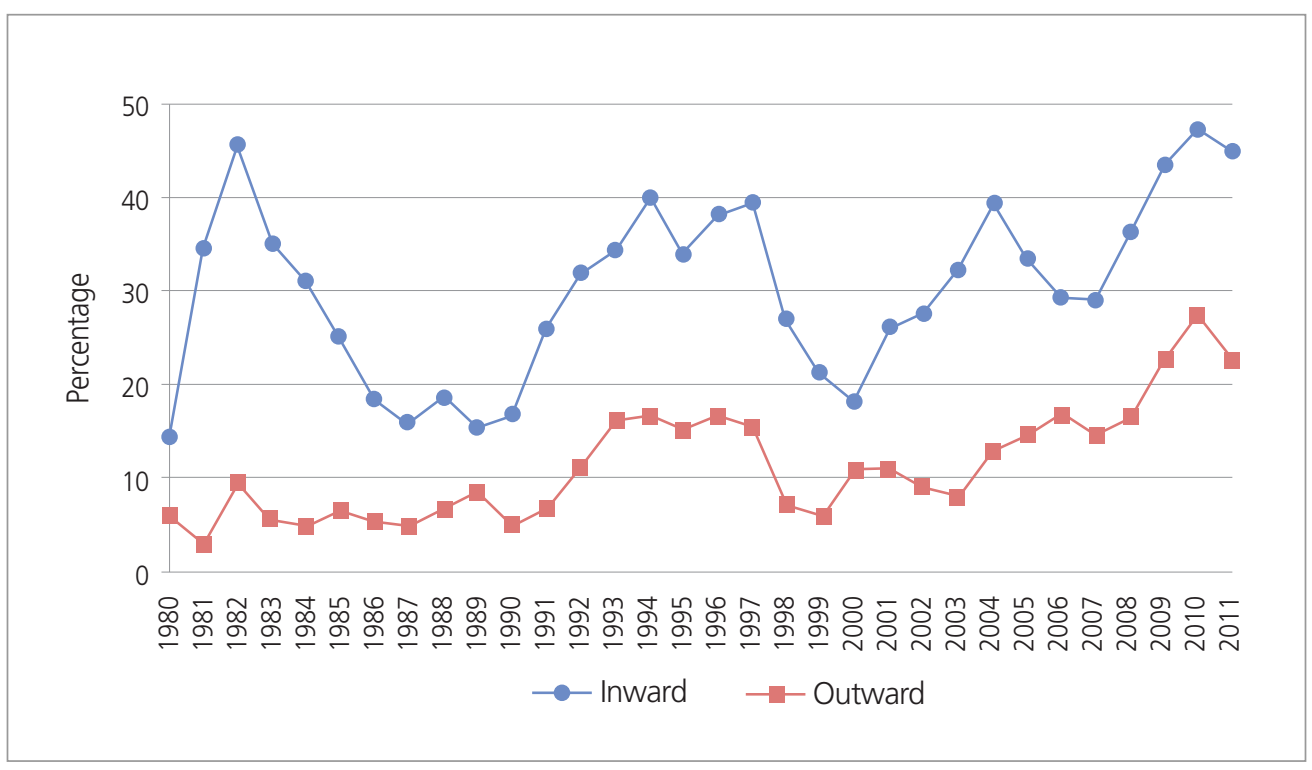

(Source) UNCTAD Statistics (2012).

The outflows and inflows of developing countries as a percentage of Gross Fixed Capital Formation (GFCF) were also on an upward trend as shown in Figure 3, with inflows higher than outflows during the entire period. Both flows peaked in 2000 with inflows reaching $16 \%$ of GFCF, dropped precipitously in 2003 and then recovered thereafter and reached another peak in 2007, although lower than in 2003. Both dropped again in 2009, the second year of the recession. 
Figure 3. FDI in developing economies as percentage of gross fixed capital formation

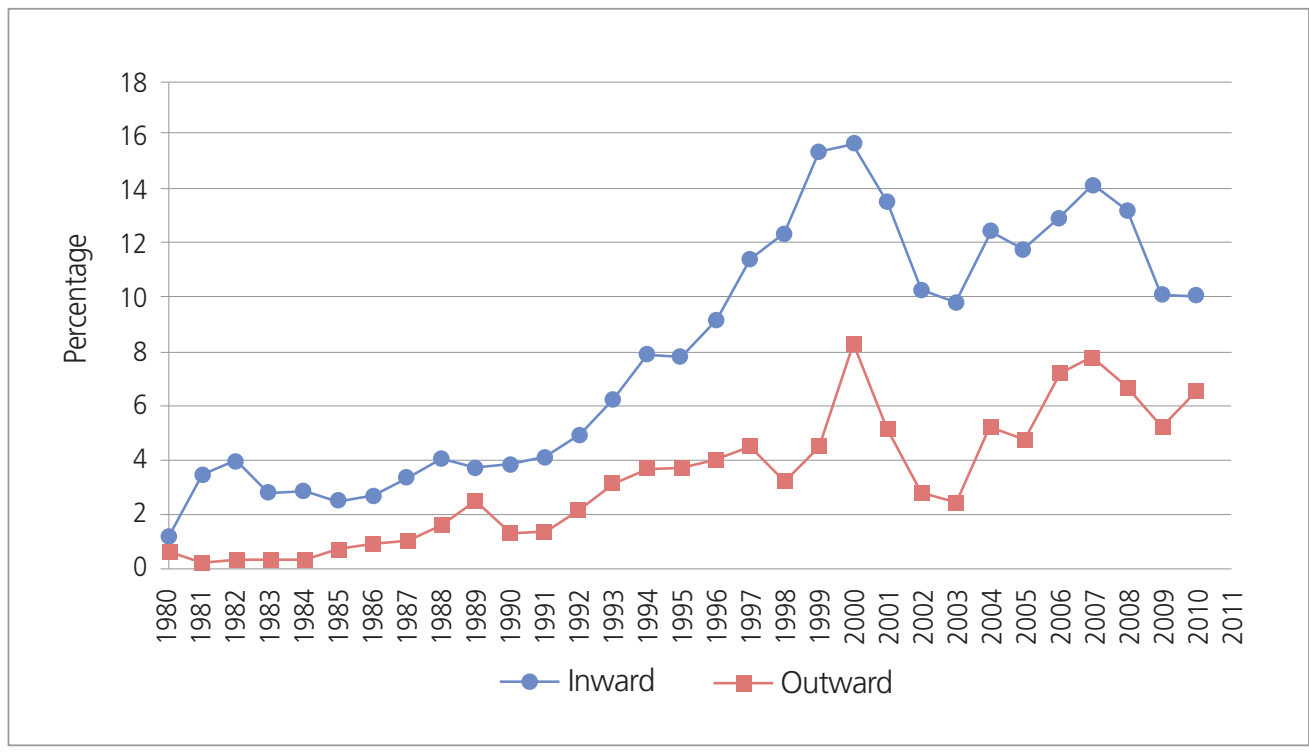

(Source) UNCTAD Statistics (2012).

During the same period of 1980 2011, developed-country FDI outflows as a percentage of the world outflow dropped from $94 \%$ to $73 \%$. FDI inflows into developed countries as a percentage of world inflows declined from $86 \%$ to $49 \%$. Compared with the outflows, which follow a relatively smooth curve, FDI inflows into developed countries show sharper fluctuations as shown in Figure 4. FDI inflows and outflows as a percentage of the GDP of developed countries follow each other closely, with outflows generally exceeding inflows, and with both peaking in 2000 and again in 2007 as shown it can be seen from Figure 5. The first peak in 2000 followed closely to the 1997 1998 Asian financial crises, while the second peak came just before the 2008 downturn. 
Figure 4. FDI flow in developed economies

(as percentage of world flows)

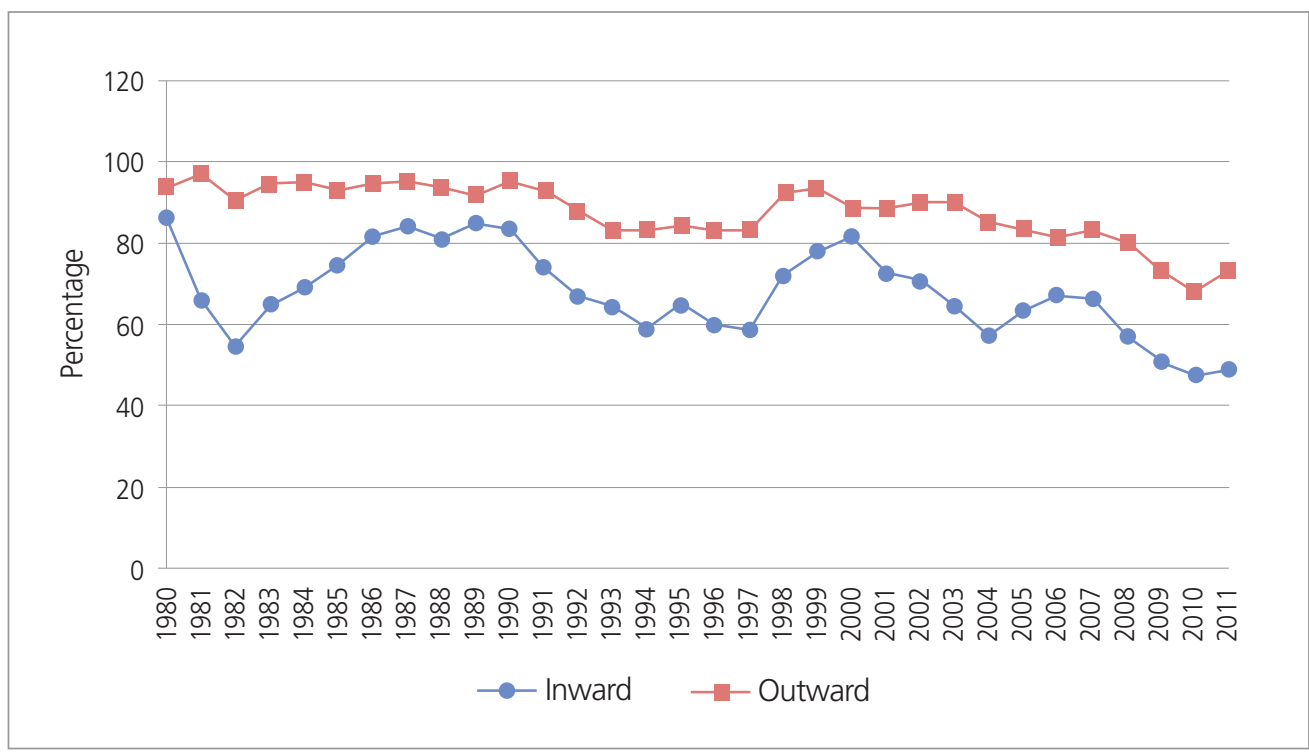

(Source) UNCTAD Statistics (2012).

FDI to developed countries grew more than 16 times over the 30-year period 1980 2011 from 46.6 billion US dollars to 747.9 billion US dollars. During the same period inflows to developing countries grew at a much faster rate, from 7.5 billion US dollars to 684.4 billion US dollars. Over the same period, average FDI inflows to developed countries grew by $14.4 \%$, to developing countries $20.6 \%$, to Japan $3.8 \%$, to Asia as a whole (i.e., South, East and Southeast, excluding Japan) 18.9\% and to Southeast Asia 20.8\%. Less than half of total FDI inflows in 2011 went to developing countries, with more than half of inflows still going to the developed countries. This means that the rich countries were still each other's major investors. 


\section{Figure 5. FDI flow in developed economies as percentage of GDP}

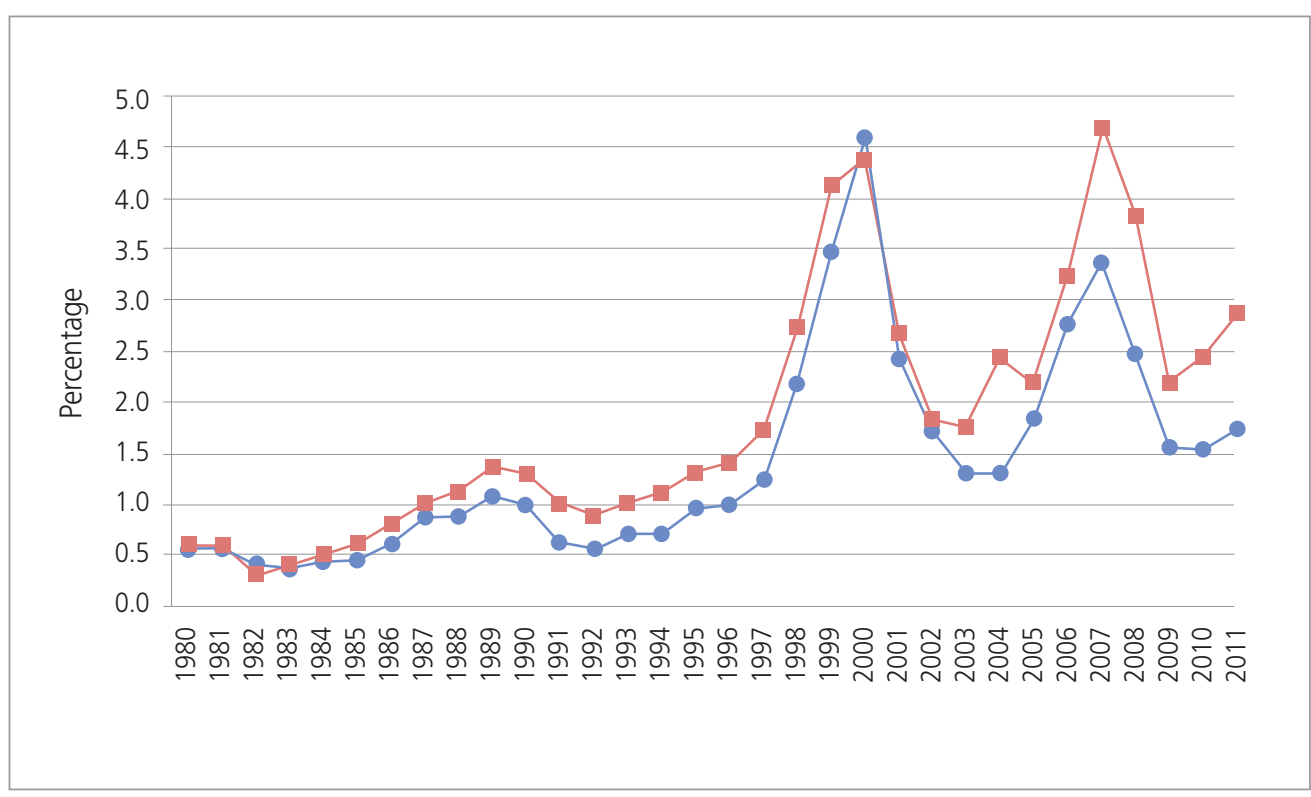

(Source) UNCTAD Statistics (2012).

In terms of FDI outflows, the two sets of countries differ dramatically. FDI outflows from developed countries grew more than 25 times, from 48.4 billion US dollars to 1237.5 billion US dollars; however, FDI outflows from developing countries grew 120 times, from a mere 3.2 billion US dollars in 1980 to 383.8 billion US dollars in 2011. This is reflected in the high average annual growth rates of FDI outflows between 1980 and 2011: 16\% for developed countries, 26\% for developing countries, 32\% for the whole of Asia (East, South and Southeast) and 32\% for Southeast Asia. It should be noted that FDI outflows from developing countries were very small, or virtually nil, at the start of the period, which partly explains the large percentage increases in subsequent years.

With FDI outflows from developing countries growing faster than those from the developed world, it could be expected that their percentage share of total FDI outflows would increase. This is what occurred with the share of total world outflows of developing countries increasing from less than 2\% in 1975 (when data first appeared on outward FDI from developing countries) to $6.4 \%$ in $1985,15.3 \%$ in 1995 and over $23 \%$ in 2011. Although there were years when the percentage share of developing countries decreased, their average share of FDI outflows for the entire period was $11.4 \%$, which is 
far higher than their initial 2\% share (Figure 5).

As a result of investment flows during past decades, the world's investment landscape has changed (Figures 6 and 7). The traditional sources and recipients of FDI, all of which are developed countries, namely Germany, Japan, Switzerland, the Netherlands, the US, the UK, and to some extent Australia, still dominate the world's investment landscape.

\section{Figure 6. Percentage of world's outward FDI stock in selected countries}

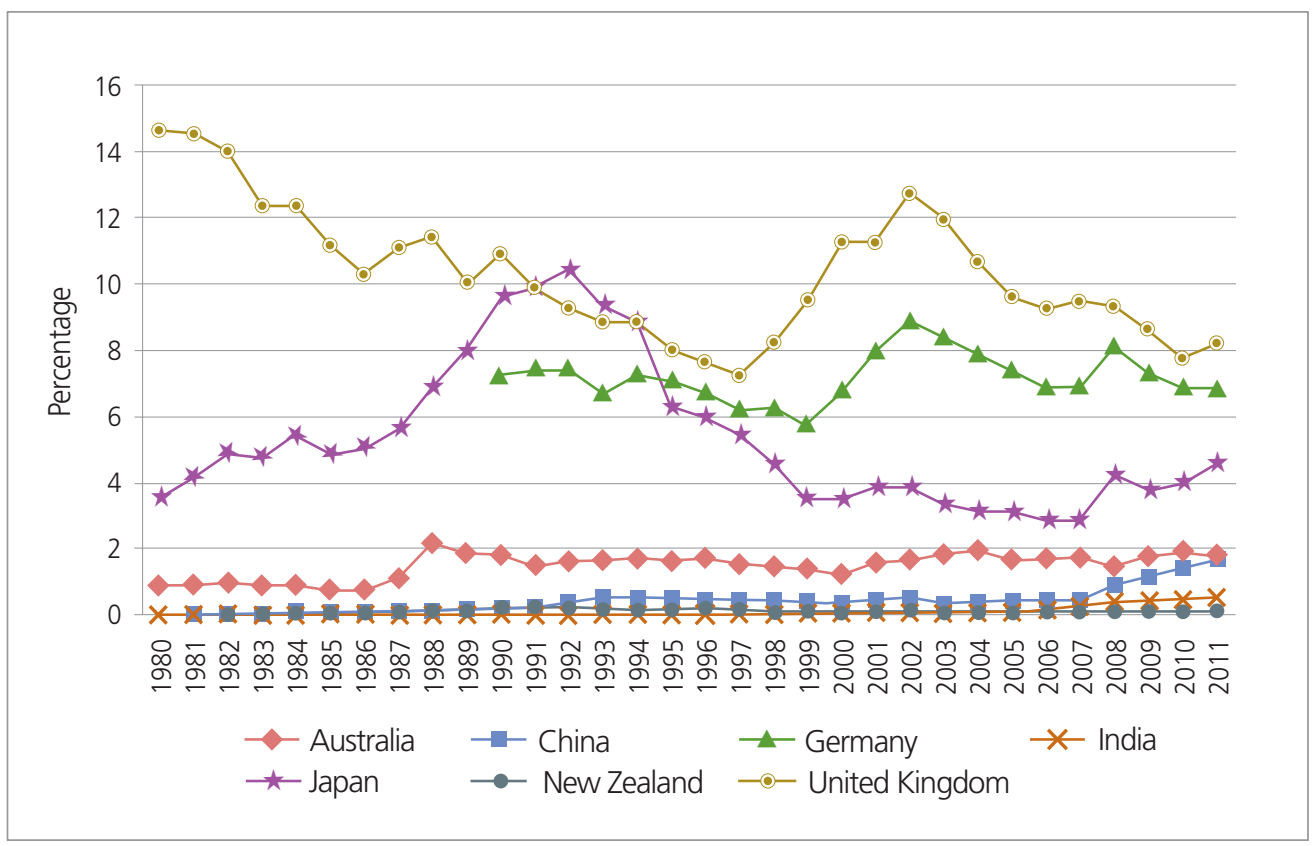

(Source) UNCTAD Statistics (2012).

As in the case of FDI flows, the distribution of inward and outward FDI stock has been highly unequal. The share of developing countries in outward FDI stock increased only slightly from $13 \%$ of the total in 1980 to $14.2 \%$ in 2009 and decreased between the two end points, although the percentage share of East Asia rose from 2.4\% in 1980 to $7 \%$ in 2009 and that of Southeast Asia from $0.2 \%$ to $1.8 \%$. During the same period, the percentage share of developed countries increased initially and then decreased.

In terms of inward FDI stock, the percentage share of developing countries decreased from $43 \%$ in 1980 to $23 \%$ in 2000 and then increased to $32 \%$ in 2011 . The percentage share of East Asia declined from 26\% in 1980 to $10 \%$ in 2011, while that of Southeast Asia increased only slightly from $3.6 \%$ to $5.3 \%$. The percentage share of developed 
countries in inward FDI stock increased from 57\% in 1980 to $75 \%$ in 1990 and then remained more or less steady at 76\% in 2000 before declining to 64\% in 2011.

Figure 7. Percentage of world's inward FDI stock from selected countries

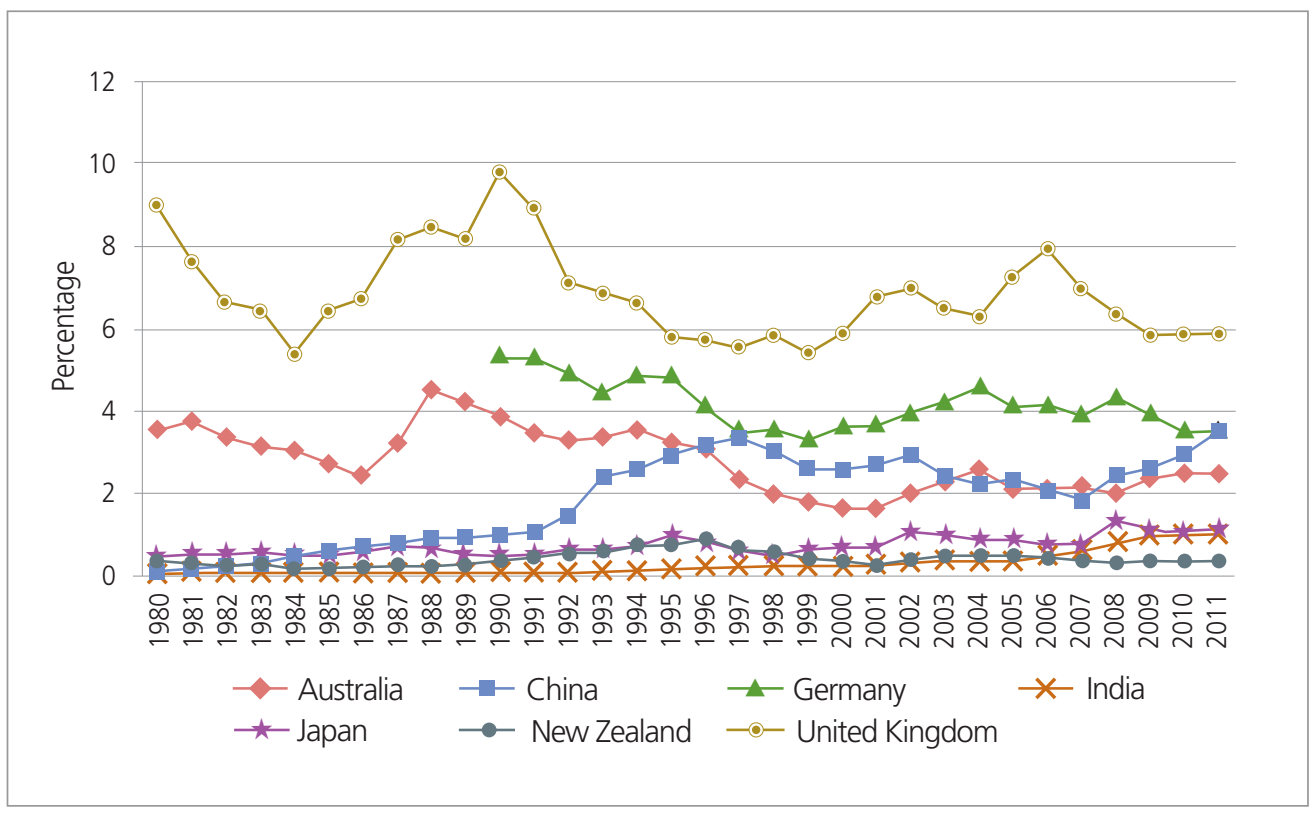

(Source) UNCTAD Statistics (2012).

How can the increasing share of developing countries in the annual FDI inflows and outflows that we noted earlier be reconciled with their decreasing share of the inward FDI stock? One probable explanation is that, although FDI outflows from developing countries increased during the period, most probably to developed countries (as in the earlier examples of Volvo and National Foods, though these cases may not necessarily be representative), thereby increasing the latter's inward FDI stock. Another possibility is that there may be investment withdrawals from developing countries as Multinational Corporations (MNCs) seek more investment-friendly hosts because in general, developing countries are less stable than developed countries. 


\section{B. East, Southeast, and South Asia}

Combining the share of developing countries in both flows conceals the highly unequal shares among the developing countries in FDI outflows and inflows. Disaggregation of the data shows that only a small group of countries account for a large share of total FDI outflows and inflows. These are East Asia, Southeast Asia and South Asia, in particular, India. In 2006, almost 60\% of total FDI outflows from developing countries came from Asia, and within Asia $80 \%$ of the total came from East Asia (excluding Japan). Hong Kong (China), the Peoples' Republic of China, Taiwan and South Korea account for the bulk of the region's FDI outflows. The increase is significant: FDI outflows from East Asia increased from almost zero in 1970 to more than 103 billion US dollars in 2006 and continue to increase as it can be seen from Table 3. In 2011, FDI outflows from East Asia dropped by 9\% to 180 billion US dollars (although they are higher than in 2006); whilst those from Southeast Asia rose by $36 \%$ to 60 billion US dollars, comprising one-third of the FDI outflows from East Asia. In Southeast Asia, FDI outflows from Singapore, Thailand and Malaysia increased the most according to UNDP (xviii 2012).

China is particularly interesting. In 1981, China's FDI outflows were a mere 44 million US dollars, slightly over one-tenth of its inflow of 430 million US dollars. The ratio of outward to inward FDI was 1:4 in 1990, 1:3 in 2006 and 1:2 in 2009. If the trend during the past few years continues, China's outward FDI will outstrip its inward FDI.

In Southeast Asia, the five ASEAN member-countries of Singapore, Malaysia, Indonesia, Thailand and Vietnam accounted for more than $90 \%$ of the total FDI outflows from the region in 2006, with the remainder being shared among the Philippines and four other ASEAN member-countries (Brunei, Cambodia, Laos, and Myanmar). Similarly, with FDI inflows, the same five ASEAN countries, particularly Singapore, received the largest share.

Thailand is an interesting case because during 2008 2009, its FDI outflows and inflows became close to parity. This happened despite the domestic political turmoil. In 1980, when Thailand had only 3 million US dollars in outward FDI whereas Vietnam had none, the Philippines already had 86 million US dollars in outward FDI. Overall, the Philippines' relative position as a source of FDI has deteriorated relative to that of its neighbors. What is true of the Philippines' FDI outflows is also true of its inflows. In 1980, or five years after the end of the Vietnam War, Vietnam had FDI inflows of only 1.67 million US dollars, while the Philippines already had 114 million US dollars. 
Twelve years later, FDI inflows to the Philippines, at 1.2 billion US dollars, were still higher than those of Vietnam with just over 900 million US dollars. A year later, FDI inflows into Vietnam surpassed those of the Philippines, and since then the former have consistently outperformed the latter, except for three years, one during the Asian financial crisis and the other two in its aftermath. By 2010, FDI inflows into Vietnam were five times those of the Philippines, and growing.

In South Asia, India accounted for most of the region's FDI outflows, which started modestly with a mere 4 million US dollars in 1980. Outflows grew in subsequent years to reach 119 million US dollars in 1995, almost 3 billion US dollars in 2005, 14.3 billion US dollars in 2006, 17.2 billion US dollars in 2007 and 18.5 billion US dollars in 2008, before decreasing to 14.9 billion US dollars in 2009. In 2011, FDI outflows from India partly recovered the lost ground, rising by $12 \%$ to 15 billion US dollars. Among developing and transition economies, India remained the largest investor in less-developed countries, followed by the People's Republic of China and South Africa (UNDP 2012, xxix).

FDI inflows to India have grown even faster than outflows from India: from 79.2 million US dollars in 1980, to 237 million US dollars ten years later and to 3.59 billion US dollars in 2000. In 2006, annual FDI inflows exceeded 20 billion US dollars and later peaked at 42.5 billion US dollars in 2008 , before decreasing to 35.6 billion US dollars in the following year, as shown in the Appendices. In 2009, FDI inflows into India were more than $80 \%$ of all FDI inflows to South Asia, while the proportion of outflows from India was even higher at $98 \%$ of the total from South Asia. India has a clearly dominant position in South Asia on both sides of the investment flow, in the same way that Singapore is dominant in Southeast Asia and China in East Asia (excluding Japan). Both China and India have populations in excess of one billion; however, Singapore is a tiny city-state with a small population. Size does matter, with some exceptions (Tables 4, 5 and 6).

\section{Interpreting Outward Flows}

How may the FDI trends, patterns and tendencies observed in the preceding sections be explained? As we have pointed out, the bulk of FDI from the developing world 
originated from a small group of countries in East Asia, Southeast Asia and South Asia. Individually, and as a group, these countries have in recent years experienced rapid and sustained economic growth as well as fundamental structural transformation. By the end of the $20^{\text {th }}$ century, some of them, such as Singapore and South Korea, had achieved developed-country status. China is now the world's second largest economy, overtaking Japan.

Levels and rates of GDP growth as well as of income per capita are an indication of an economy's wealth and productivity and its potential to save and invest. The larger a country's GDP and the higher its per capita income and the faster these are growing, the greater are the resources available for investment in the domestic economy or in other countries. High income levels and rapid economic growth not only attract inward FDI (size of the domestic market being an important pull factor), but they also drive outward FDI by raising the country's marginal propensity to save and invest. Thus, our first hypothesis is:

Hypothesis 1: FDI outflows are positively associated with rising levels of GDP or rapid economic growth.

The fast-growing countries of East, Southeast and South Asia that have relatively high outward FDI also have high domestic savings rates. During its period of rapid overseas expansion in the 1960s 1980s, Japan had very high savings rate. Singapore, which is currently the source of substantial outward FDI from Southeast Asia, also has one of the highest savings rates in the world, at almost 50\%. The best current example is China, which has one of the largest and fastest-growing outward FDI and one of the world's highest savings rates for a large economy.

Moving from individual countries to groups of countries, the same observation of high savings rate and high outward FDI is also evident. For the period 2001 2010, the average savings rate of the world as a whole was $21.3 \%$; but the average savings rate of the small group of countries in East, Southeast and South Asia with high and growing outward FDI was over $38 \%$, almost double that of the world average. There are exceptions: relatively low savers such as the Philippines, Cambodia and Myanmar, whose inclusion reduces the region's overall savings rate to $31 \%$. Nevertheless, the average savings rate of these countries is still significantly above the world average. High domestic savings are important as a source of investment, both in the domestic economy or abroad. Thus, our second hypothesis is:

Hypothesis 2: FDI outflows are positively associated with domestic savings.

Most countries that are in receipt of large FDI inflows and have themselves become 
sources of substantial outward FDI, also have a strong trade orientation indicated by high export-to-GDP ratios. Japan best exemplified this feature in earlier decades, as did (and still does) Germany. In subsequent decades, Singapore, Taiwan, South Korea and Hong Kong have become export powerhouses. China is the best contemporary example. The seeming exception to the close connection between export-orientedness and high outward FDI that characterizes the region is India, which for decades since the independence, pursued policies that were anchored on socialist-style planning and economic self-sufficiency. That has now changed with India, becoming a major exporter of manufactured goods and IT services. Indian firms are also well represented among the world's multinationals.

The move of a firm from exporting goods or services to investing abroad follows the well-known product life-cycle theory, according to which a firm first exports to a foreign country, while in the process gaining familiarity with the foreign market, and then establishes a production facility in the latter (now the host country), becoming a multinational firm as a result. Our third hypothesis is:

Hypothesis 3: FDI outflows are positively associated with strong export-orientation.

Countries with large international reserves, such as China with 2 trillion US dollars in 2008, Taiwan and Singapore, are also countries with large and rapidly-growing outward FDI. The size of a country's international or foreign exchange reserves indicate not only a country's capacity to import goods and services and meet its maturing debt obligations but also its capacity to invest in other countries. Thus, our fourth hypothesis is:

Hypothesis 4: FDI outflows are positively associated with foreign exchange reserves.

Evidence suggests that countries that are important sources of outward FDI have once been or concurrently are recipients of substantial FDI inflows. Banga (2008) identifies inward FDI to developing (host) countries as an important capacity driver of outward FDI from these (home) countries. This occurs because FDI inflows bring with them not only capital but also technology, organizational/managerial skills and networks, each or all of which have the intended or unintended effect of enabling local managers and domestic entrepreneurs (who may either be partners or competitors of foreign investors) and thus preparing them for their overseas move as investors, should they decide to make such a move. Thus, our fifth hypothesis is:

Hypothesis 5: FDI outflows are associated positively with FDI inflows. 


\section{Tests of Hypothesized Relationships}

\section{A. Data source}

The data used in this paper were collected from two databases. The data on GDP and GDP per capita were retrieved directly from the International Monetary Fund (IMF), World Economic Outlook (WEO) Database (2011 and 2012). The original data on GDP were also obtained from the WEO Database. FDI inflows and outflows were taken from the UNCTAD Yearbook 2012 (and previous years). Country-specific total reserves and export values were retrieved from the World Bank Database (2012 and other years). All data are in billions of current US dollars.

\section{B. Correlation analysis}

To test the hypothesized relationships, we performed correlation and regression analyses. Pearson correlations were performed on outward FDI and savings rate (as percent of GDP), outward FDI and GDP, outward FDI and GDP per capita, outward FDI and foreign reserves, outward FDI and exports and outward FDI and FDI inflows for the years 1990 2010. The results are presented in Table 2. 
Table 2. Correlation analysis

$(1990 \sim 2011)$

\begin{tabular}{|l|c|c|c|c|c|c|}
\hline \multicolumn{1}{|c|}{ Country } & $\begin{array}{c}\text { FDI and } \\
\text { Savings }\end{array}$ & $\begin{array}{c}\text { FDI and } \\
\text { GDP }\end{array}$ & $\begin{array}{c}\text { FDI and GDP } \\
\text { per capita }\end{array}$ & $\begin{array}{c}\text { FDI and } \\
\text { Reserves }\end{array}$ & $\begin{array}{c}\text { FDI and } \\
\text { Exports }\end{array}$ & $\begin{array}{c}\text { FDI and } \\
\text { FDI inflows }\end{array}$ \\
\hline China & $0.949^{* *}$ & $0.939^{* *}$ & $0.939^{* *}$ & $0.948^{* *}$ & $0.902^{* *}$ & $0.860^{* *}$ \\
\hline India & $0.916^{* *}$ & $0.902^{* *}$ & $0.906^{* *}$ & $0.935^{* *}$ & $0.930^{* *}$ & $0.968^{* *}$ \\
\hline Indonesia & $0.612^{*}$ & $0.735^{* *}$ & $0.734^{* *}$ & $0.638^{*}$ & $0.818^{* *}$ & $0.693^{* *}$ \\
\hline Malaysia & $0.935^{* *}$ & $0.939^{* *}$ & $0.926^{* *}$ & $0.902^{* *}$ & $0.907 * *$ & $0.656^{*}$ \\
\hline Philippines & 0.368 & 0.384 & 0.383 & 0.335 & 0.405 & 0.469 \\
\hline Thailand & $0.929 * *$ & $0.935^{* *}$ & $0.933^{* *}$ & $0.959^{* *}$ & $0.882^{* *}$ & 0.446 \\
\hline All Countries & $0.917^{* *}$ & $0.912^{* *}$ & $0.426^{* *}$ & $0.925^{* *}$ & $0.892^{* *}$ & $0.846^{* *}$ \\
\hline
\end{tabular}

(Source) World Bank 2012, UNCTAD 2012.

(Notes) (i) Country selection is on the basis of $2^{\text {nd }}$ tier East Asian developing economies. (ii) ** Significant at the 0.01 level (2 tailed) * Significant at 0.05 level ( 2 tailed).

The results generally confirm the hypothesized relationships. The exception is the Philippines, which has a low and statistically insignificant relationship between outward FDI and the other variables. China, India, Malaysia and Thailand all show very strong relationships, while Indonesia also has a fairly strong relationship between outward FDI and the other variables. There is also a statistically highly significant correlation between outward FDI and GDP and GDP per capita in most of the countries. Overall, the analysis clearly indicates fairly strong or very strong relationships between outward FDI, domestic savings rate, GDP, foreign reserves, exports and inward FDI for each country individually and as a group.

\section{Regression analysis}

Ordinary least squares regression was used to test the econometric relationship and the impact of selected macro-economic indicators on the outward FDI of China, India, Indonesia, Malaysia, the Philippines and Thailand. The data used were taken from the World Bank's Development Indicators for various years. The tested model (with results in Table 3) is: 


$$
F D I_{\text {outward }}=\alpha+\beta_{1} G D P+\beta_{2} \text { Savings }+\beta_{3} \text { Reserve }+\beta_{4} \text { Export }+\beta_{5} F D I_{\text {inflow }}+\varepsilon
$$

where:

$F D I_{\text {outward }}=$ Foreign Direct Investment Outflows; $F D I_{\text {inflow }}=$ Foreign Direct Investment Inflows $G D P=$ Gross Domestic Product; Savings = Domestic Savings;

Reserve $=$ Reserve; Export $=$ Exports

Table 3. Factors affecting outward Foreign Direct Investment

(1990 2011)

\begin{tabular}{|l|c|c|c|}
\hline Independent Variables & Coefficient & Standard Error & $p$ values \\
\hline Gross Domestic Product & 0.017 & 0.004 & 0.0006 \\
\hline Savings & -0.039 & 0.0139 & 0.006 \\
\hline Reserves & 0.0359 & 0.008 & 0.0000 \\
\hline Exports & -0.0121 & 0.008 & 0.144 \\
\hline FDI inflows & 0.0646 & 0.054 & 0.236 \\
\hline Constant & -0.589 & 0.617 & 0.342 \\
\hline Observations & 126 & & \\
\hline $\mathrm{R}^{2}$ & 0.87 & & \\
\hline
\end{tabular}

The results show that the most significant factors affecting outward FDI in the six countries are foreign reserves and GDP, both having significant positive effects on outward FDI. The remaining variables, on the other hand, show ambiguous effects on outward FDI. For example, the effects of savings and exports on outward FDI are negative, which is opposite to our hypotheses. Moreover, although the effect of inward FDI on outward FDI is positive, it is insignificant. We therefore performed additional tests using extended models. 


\section{Regression analysis: extended models}

In order to capture the patterns and other characteristics of outward FDI, our earlier model is extended by using additional variables and three different levels: individual countries, country groups classified by development level and the whole/combined dataset. All data are from 1990 to 2011. Countries included are Australia, China, India, Indonesia, Malaysia, New Zealand, the Philippines, and Thailand. The datasets for GDP and GDP per capita were retrieved from the World Economic Outlook Database of the IMF $(2011,2012)$ and the dataset for total savings comes from the authors' calculations of gross national savings as percentage of GDP from the same database. The datasets on FDI inflows and outflows, total foreign reserves and exports were retrieved and calculated from the World Bank Database. All data are in billions of current US dollars.

The extended models can be summarized through the following formulations:

Model 1:

$F D I(\text { outflow })_{t}=\alpha+\beta_{1} G D P_{t}+\beta_{2} G D P_{t-1}+\beta_{3} G D P_{t-2}+\beta_{4} F D I(\text { inflow })_{t}+$ $\beta_{5} F D I$ inflow $_{t-1}+\beta_{6} F D I$ (inflow $_{t-2}+\beta_{7} S_{A V I N G}+\beta_{8} S_{t} A V I N G_{t-1}+$ $\beta_{9}$ SAVING $_{t-2}+\beta_{10}$ RESERVE $_{t}+\beta_{11}$ RESERVE $_{t-1}+\beta_{12}$ RESERVE $_{t-2}+$ $\beta_{13}$ Export $_{t}+\beta_{14}$ Export $_{t-1}+\beta_{15}$ Export $_{t-2}+\varepsilon$

Where

$t=$ at time $t$ (current year); $t-1=$ previous year; $t-2=$ previous two years.

We also used two other models to examine whether population can affect the results significantly because China and India both have very large population. These two models are similar to the above models; the only modification being the replacement of GDP by GDP per capita and $\ln$ GDP by $\ln$ GDP per capita.

Model 2:

$F D I(\text { outflow })_{t}=\alpha+\beta_{1} \ln G D P_{t}+\beta_{2} \ln G D P_{t-1}+\beta_{3} \ln G D P_{t-2}+\beta_{4} F D I(\text { inflow })_{t}+$

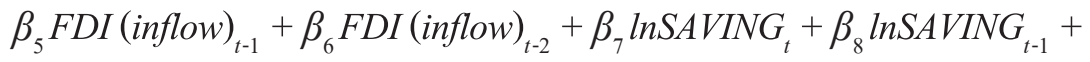
$\beta_{9} \ln S A V I N G_{t-2}+\beta_{10} \ln R E S E R V E_{t}+\beta_{11} \ln R E S E R V E_{t-1}+$

$\beta_{12}$ InRESERVE $_{t-2}+\beta_{13}$ Export $_{t}+\beta_{14}$ Export $_{t-1}+\beta_{15}$ Export $_{t-2}+\varepsilon$

The use of GDP per capita instead of GDP does not make a significant difference in 
explaining FDI outflows, hence the results using GDP per capita are not reported here. We also tested the exports variable using two-period time lags for different countries and country groups. The results showed mixed and insignificant effects of lagged exports on outward FDI flows, so we reported only one of them in our findings for individual countries.

\section{E. Results for individual countries}

The two most significant single-regressor results, one multiple-regressor result that comprised all five variables and the most significant multiple-regressor results that we can obtain for each country, are shown in Table 8 (parts 1-3). Several patterns and observations can be deduced from the regression results using the extended models. First, at the individual country level, GDP, total savings, international reserves, FDI inflows and exports-to-GDP differ in their explanatory power for the outward FDI of different countries. For instance, in case of Australia FDI inflows are the most powerful regressor for FDI outflows, explaining $81 \%$ of changes; but in case of New Zealand FDI inflows can only explain $12 \%$ of the changes in FDI outflows. This differential effect is also present among the developing countries in our sample. For example, while the explanatory power of FDI inflows is $93 \%$ for India, it is only $19 \%$ for the Philippines. Similar differences can be found for GDP, total savings, total reserves and exports when these are used as single regressors. The five regressors also show similar explanatory power for a single country's FDI outflows, except for Australia, where FDI inflows are more powerful than other regressors in explaining FDI outflows. For example, the adjusted R-square of Thailand's regression has a value between $87 \%$ and $96 \%$, but for the Philippines, its value is only between $13 \%$ and $18 \%$ (Table 8 , parts $1-3$ ).

Second, regression results using GDP, total savings, total reserves, FDI inflows and exports-to-GDP as variables exhibit interactions between them as shown by the multipleregressor results and their similar explanatory power for one particular country. For instance, the adjusted R-square of India's regression (4) is $99 \%$, but the coefficient for reserve $_{\mathrm{t}-1}$ is -0.09 , which means that when the reserves of India increase by 1 billion US dollars, FDI outflows in the following year decrease by about 2 million US dollars. This may be explained by multicollinearity problems. As mentioned before, the explanatory power of most models is very high, which confirms the finding of our preliminary analyses and also supports our hypotheses; however, because the regressors are highly 
correlated with each other (e.g., the correlation between Chinese GDP and savings is 0.99 and that between India's GDP and savings is also 0.99), there may be no way to determine the causality between them through the available data.

Third, another characteristic shown by the above results is that FDI outflows are related to the total amount of the regressors instead of changes in them. In all eight countries included in the sample, only one logarithmic regressor can be included among the top three significant regressors.

Finally, with lags taken into consideration, GDP, total savings and total reserves are statistically significant determinants of a country's FDI outflows, but FDI inflows and exports have no such effects. Time-lagged reserves are especially important for China, Malaysia and Thailand. In all three countries, reserve ${ }_{t-1}$ by itself can explain about $90 \%$ of the changes in FDI outflows, with the coefficients being significant at the $0.01 \%$ level.

\section{F. Results for country groups}

To determine whether the above results also hold at the country group/general level, panel data on developed countries, developing countries and the whole dataset were also used in our models. The most significant results for each country group are reported in Table 9. For developed and developing countries, a single regressor still has explanatory power for changes in FDI outflows. These are reported in the first two columns of Table 7.

The patterns and characteristics of FDI outflows of developed countries differ from those of developing countries. First, FDI inflows are the most important factor in explaining FDI outflows in developed countries. Even the most significant multipleregressor regression can only increase the explanatory power of single FDI inflows from $82 \%$ to $87 \%$ and most of the coefficients of the other regressors are statistically not significant. Exports and savings of the previous year are two factors that can also partly explain changes in FDI outflows of developed countries. For developing countries, on the other hand, the most powerful explanatory factor is the home country's international reserves of the previous year. ${ }^{13}$ Previous year GDP and FDI inflows also have satisfactory explanatory power, although not as much power as reserve ${ }_{t-1}$. The multiple regression results for developed and developing countries show the difference more clearly. For developed countries, FDI inflows are the single most important factor in explaining FDI

\footnotetext{
${ }^{13}$ International reserves comprise holdings of monetary gold, special drawing rights, reserves of IMF members held by the IMF and holdings of foreign exchange under the control of monetary authorities (World Bank 2012).
} 
outflows. No significant relationships are observed between FDI outflows and either GDP or total savings. For developed countries, total reserves and previous year reserves have an ambiguous relationship with FDI outflows. For developing countries, GDP, domesic savings and previous year reserves are the most important factors in explaining FDI outflows, and FDI inflows have no significant realtionship with FDI outflows.

Another pattern that can be observed from the results is that, compared with other regressors in our model, total savings are a weak regressor for explaining changes in FDI outflows. This may be explained by the Feldstein effect. Although some results show that lagged savings have similar effects as GDP, the total effect of savings is not clear.

The results for the whole sample are also reported. Compared with developed and developing-country groups, the results for the whole dataset do not have the same significance. An explanation for this is that the special characteristics of developed and developing countries are weakened in the whole data set because the results are mixed; however, the results show that FDI inflows, GDP and reserves are related positively to FDI outflows.

How can the observed differences in the patterns and characteristics of FDI outflows of developed and developing countries be explained? For the developed countries, which have experienced long-term, high-growth development, FDI outflows have two motives. First, to invest in rapidly-growing developing countries in order to obtain higher returns than that can be had in the firm's domestic economy. Where capital is abundant, as in a developed-country, the marginal return on investment is generally low. Where capital is scarce, as in a less-developed country, the marginal return is generally higher. Second, MNCs use FDI as a financial instrument to hedge financial risks, in other words, as a risk diversification strategy. The first inference can explain why there is no observed relationship between FDI outflows and GDP in these countries. The second can explain the significant relationship between FDI outflows and FDI inflows. Catch-up effects, because developing countries are experiencing long-term economic growth, will cause FDI outflows to grow at the same pace as other variables such as GDP, FDI inflows and reserves.

Our study differs from most other studies on FDI outflows in that it focuses on the push factors in the home or source countries instead of the pull factors in the host countries. In addition, other studies have used variables such as high domestic production costs (principally in the form of high wages) as an important driver of outward FDI. We have considered different variables including GDP, GDP per capita, export orientation and the openness of the economy, as indicated by high exports-to-GDP ratios, high 
foreign reserves, capital abundance from high domestic savings rates and inward FDI, which transfers technology and other capabilities to the host (now home) country.

\section{Conclusion}

Our study shows that the relationships between outward FDI and domestic savings, GDP, GDP per capita and FDI inflows for selected countries are generally strong, but the importance of the variables differs between developed and developing countries. FDI inflows are an important determinant of developed-country outflows. For developing countries, GDP, exports and international reserves are statistically important determinants for outward FDI. Overall, the findings suggest that for a developing country to aspire to be a capital exporter through FDI, it must possess all or most of the following: high domestic savings rate, an export-oriented economy, a GDP that is growing rapidly and substantial international reserves. In short, for a developing country to become a capital exporter through FDI, it needs to grow, save and look outward.

What are some implications of these outcomes? Are they good or bad, positive or negative, for the countries involved and for the world as a whole? We believe that the rise of new economic players of new firms from developing or newly-developed countries that are able and willing to invest in other countries, is a positive development, both for economic well-being and for world peace and stability. FDI tends to lead to economic prosperity in both the home and host country - although some sectors, such as workers in the home country and capitalists in the host country, may experience losses in the short term. If, however, the investment (whether coming from traditional or new sources) leads to a more efficient allocation of resources, society as a whole stands to gain in the long run.

Given that a new pattern of FDI has emerged, what policies, either derived from our findings or from other studies, should be considered at both the national and regional or international levels to enable and encourage more countries to participate?

At the national level:

- Competition policies should be pursued by governments. These policies encourage national and international investment. 
- Outward-looking policies, the integration of national economies into the global order, are usually favorable for growth and development. Raise domestic savings rate as a source of domestic and foreign investment.

- To succeed in the international market, a country must offer a product or service that is superior in price or quality to that offered by others. Negotiate with foreign investors for training and transfer of technology to domestic firms.

- Encourage and support the formation of industry clusters. Globally-competitive firms have usually come from industry clusters defined by Michael Porter (1990) as geographically concentrated firms that compete as well as collaborate.

At the regional/international level:

- Pursue efforts to reduce barriers to the free flow of goods and services, capital and labor, either unilaterally or in the context of regional economic integration.

- Encourage access to the domestic markets of industrialized countries by reducing barriers. A way for nations to resolve their conflicts through peaceful and diplomatic means and not through force or threats. Rapid growth and development occurs in peaceful time periods rather than in conflict periods.

Finally, what future directions should research on this topic take? We have examined the macro-level factors that drive developing-countries to invest abroad. Studies at a firm, industry or sector level are a logical next step. We are aware of research in this area, but there is scope for further analysis. Studies could address two broad issues. At the empirical level, what are the differences, if any, between developing-country multinationals and the multinationals established earlier in developed countries? At a theoretical level, are the traditional theories of the multinational corporation, associated, for example, with Dunning, Hymer (1979) and Vernon (1966) and which were primarily derived from the experience and in the context of the more developed countries, adequate to explain the new phenomenon of reverse FDI?

Received 28 June 2013, Revised 8 October 2014, Accepted 20 April 2015 


\section{References}

Banga, R. "Drivers of Outward Foreign Direct Investment from Asian Developing Economies." Asia-Pacific Trade and Investment Review 4 (2008): 195-215.

Bloomberg Businessweek. "Zhejiang Geely Holding Group Co. Ltd.: Private Company Information." Accessed June 29, (2014). http://investing.businessweek.com/research/ stocks/private/snapshot.asp?privcapId=24602571.

Buckley, P. J., Clegg, L. J., Cross, A.R., Liu, X., Voss, H., and Zheng, P. "The Determinants of Chinese Outward Foreign Direct Investment." Journal of International Business Studies 38 (2007): 499-518.

CEMEX S.A.B. "CEMEX Building the future.” Accessed June 29, (2014). http://www. cemex.com/AboutUs/CompanyProfile.aspx.

Cheng, L.K. and Ma, Z. "China's Outward FDI: Past and Future." NBER Working Paper, Cambridge, (2007).

Cheung, Y.W. and Qian, X. "The Empirics of China's Outward Direct Investment." CESifo Working Paper, No. 2621, (2009).

Genting Group. “Genting.” Accessed June 29, (2014). http://www.genting.com/ groupprofile/ index.htm.

Huawei Technologies Co. "Huawei - A leading global ICT solutions provider." Accessed June 29, (2014). http://www.huawei.com/en/.

Hymer, S. H., and Radice, H. The Multinational Corporations and the Law of Uneven Development. London: Yale University Economic Growth Center, (1975).

IMF. “World Economic Outlook Database.” Accessed June 29, (2014). http://www.imf. org//external/pubs/ft/weo/2012/02/weodata/index.aspx.

Kayam, K. S.. Home Market Determinants of FDI Outflow from Developing and Transition Economies. Munich: Personal Repec Archive, (2009).

Kolstad, I., and Wiig, A. "What Determines Outward Chinese FDI." Journal of World Business 47 (2012): 26-34.

Lenovo. "Lenovo, For Those Who Do.” Accessed June 29, (2014). http://www.lenovo.com/ lenovo/nz/en/our_company.shtml. 
Masron, T. A., and Shahbudin, A. S. "Push Factors of Outward FDI: Evidence from Malaysia and Thailand." Journal of Business \& Policy Research 5 (2010): 54-68.

San Miguel Corporation. "San Miguel Corporation.” Accessed June 29, (2014). http:// www.sanmiguel.com.ph/company.html.

Sauvant, K. P., McAllister, G., and Maschek, W. A. "Foreign Direct Investment by Emerging Market Multinational Enterprises, the Impact of the Financial Crisis and Recession, and Challenges Ahead." Paper presented at the Global Forum on International Investment, (2009).

Tata. "Tata Leadership with trust.” Accessed June 28, (2014). http://www.tata.com.

Thai Union Frozen Products PCL by Thai Union Group. "TUF, The World's Seafood Expert.”Accessed June 29, (2014). http:/www.thaiuniongroup.com/en/profile/companyhighlights.ashx.

Tolentino, Paz Estrella. "Home Country Macroeconomic Factors and Outward FDI of China and India.” Journal of International Management 16 (2010):102-120.

UNCTAD. “Annual Report (various years).” Accessed June 29, (2014). http://unctad. org/SearchCenter/Pages/Results.aspx?sq=1\&k=Unctad\%20Annual\%20Report.

UNCTAD. "Global Investment Trends Monitor (No. 8, 24 January)." Accessed June 29, 2014. http://unctad.org/en/Pages/Publications/Global-Investment-Trends-Monitor(Series).aspx

UNCTAD. "World Investment Report (various years).” Accessed June 29, (2014). http:// unctad.org/SearchCenter/Pages/Results.aspx?sq=1\&k=World\%20Investment\%20Report Vernon, R. "International Investment and International Trade in the Product Lifecycle." Quarterly Journal of Economics 80 (1966): 190-207.

Viettel Group. "Viettel Say it your way." Accessed June 29, (2014). http://www.viettel. com.vn/About_us.html.

Wikipedia, the free encyclopedia. "Salim Group." Accessed June 25, (2014). http:// en.wikipedia.org/w/index.php?title=Salim_Group\&oldid=614360639.

Wipro Ltd. "WIPRO Applying Thought.” Accessed June 29, (2014). http://www.wipro. com/about-wipro/. 
World Bank. "World Development Indicators." Accessed June 29, (2014). http://data. wroldbank.org/data-catalog/world-development-indicators. 
Table 4. Annual growth of FDI inflow

(in Billion US dollars, current rate)

\begin{tabular}{|c|c|c|c|c|c|c|c|c|c|c|c|}
\hline Year & World & $\begin{array}{l}\text { Developed } \\
\text { Economies }\end{array}$ & $\begin{array}{c}\% \\
\text { Growth }\end{array}$ & Japan & $\begin{array}{c}\% \\
\text { Growth }\end{array}$ & $\begin{array}{r}\text { Developing } \\
\text { economies }\end{array}$ & $\begin{array}{c}\% \\
\text { Growth }\end{array}$ & $\begin{array}{c}\text { East, } \\
\text { South \& } \\
\text { Southeast } \\
\text { Asia }\end{array}$ & $\begin{array}{c}\% \\
\text { Growth }\end{array}$ & \begin{tabular}{|c|} 
Southeast \\
\& East \\
Asia \\
Excl. \\
China
\end{tabular} & $\begin{array}{c}\% \\
\text { Growth }\end{array}$ \\
\hline 1980 & $\$ 54.1$ & $\$ 46.6$ & & $\$ 0.3$ & & $\$ 7.5$ & & $\$ 3.9$ & & $\$ 3.5$ & \\
\hline 1981 & $\$ 69.6$ & $\$ 45.5$ & -2.3 & $\$ 0.2$ & -32.0 & $\$ 24.0$ & 221.5 & $\$ 6.5$ & 67.8 & $\$ 5.9$ & 68.5 \\
\hline 1982 & $\$ 58.1$ & $\$ 31.7$ & -30.4 & $\$ 0.4$ & 132.3 & $\$ 26.4$ & 9.7 & $\$ 5.6$ & -14.5 & $\$ 5.1$ & -15.0 \\
\hline 1983 & $\$ 50.3$ & $\$ 32.7$ & 3.2 & $\$ 0.4$ & -5.2 & $\$ 17.6$ & -33.4 & $\$ 5.6$ & 0.7 & $\$ 4.7$ & -7.3 \\
\hline 1984 & $\$ 56.8$ & $\$ 39.2$ & 20.1 & $\$ 0.0$ & -102.4 & $\$ 17.6$ & 0.2 & $\$ 6.1$ & 8.4 & $\$ 4.5$ & -4.1 \\
\hline 1985 & $\$ 55.9$ & $\$ 41.7$ & 6.2 & $\$ 0.6$ & -6187.1 & $\$ 14.2$ & -19.4 & $\$ 4.7$ & -22.5 & $\$ 2.6$ & -41.9 \\
\hline 1986 & $\$ 86.4$ & $\$ 70.6$ & 69.5 & $\$ 0.2$ & -60.2 & $\$ 15.8$ & 11.2 & $\$ 7.9$ & 68.1 & $\$ 5.5$ & 111.6 \\
\hline 1987 & $\$ 136.6$ & $\$ 114.8$ & 62.6 & $\$ 1.2$ & 386.3 & $\$ 21.8$ & 38.1 & $\$ 14.4$ & 82.1 & $\$ 12.0$ & 117.2 \\
\hline 1988 & $\$ 164.0$ & $\$ 133.6$ & 16.3 & $-\$ 0.5$ & -141.1 & $\$ 30.4$ & 39.6 & $\$ 17.4$ & 20.8 & $\$ 13.9$ & 15.5 \\
\hline 1989 & $\$ 197.3$ & $\$ 166.5$ & 24.7 & $-\$ 1.1$ & 119.0 & $\$ 30.7$ & 1.0 & $\$ 16.6$ & -4.7 & $\$ 12.7$ & -8.1 \\
\hline 1990 & $\$ 207.5$ & $\$ 172.5$ & 3.6 & $\$ 1.8$ & -270.4 & $\$ 34.9$ & 13.4 & $\$ 21.8$ & 31.8 & $\$ 18.1$ & 42.4 \\
\hline 1991 & $\$ 154.1$ & $\$ 114.0$ & -33.9 & $\$ 1.3$ & -28.9 & $\$ 39.8$ & 14.3 & $\$ 22.0$ & 1.0 & $\$ 17.2$ & -5.0 \\
\hline 1992 & $\$ 165.9$ & $\$ 111.1$ & -2.5 & $\$ 2.8$ & 114.6 & $\$ 53.1$ & 33.2 & $\$ 29.8$ & 35.3 & $\$ 18.1$ & 4.9 \\
\hline 1993 & $\$ 223.3$ & $\$ 143.4$ & 29.1 & $\$ 0.2$ & -92.4 & $\$ 76.7$ & 44.6 & $\$ 53.9$ & 80.6 & $\$ 25.0$ & 38.4 \\
\hline 1994 & $\$ 256.0$ & $\$ 150.6$ & 5.0 & $\$ 0.9$ & 322.2 & $\$ 103.4$ & 34.7 & $\$ 66.2$ & 22.9 & $\$ 30.5$ & 22.1 \\
\hline 1995 & $\$ 342.8$ & $\$ 222.5$ & 47.8 & $\$ 0.0$ & -95.3 & $\$ 116.2$ & 12.4 & $\$ 78.0$ & 17.8 & $\$ 37.7$ & 23.5 \\
\hline 1996 & $\$ 390.9$ & $\$ 236.0$ & 6.1 & $\$ 0.2$ & 449.9 & $\$ 149.0$ & 28.2 & $\$ 92.4$ & 18.4 & $\$ 47.3$ & 25.4 \\
\hline 1997 & $\$ 487.9$ & $\$ 285.4$ & 20.9 & $\$ 3.2$ & 1314.6 & $\$ 192.1$ & 28.9 & $\$ 103.2$ & 11.7 & $\$ 52.5$ & 11.1 \\
\hline 1998 & $\$ 706.3$ & $\$ 508.7$ & 78.3 & $\$ 3.2$ & -1.0 & $\$ 189.4$ & -1.4 & $\$ 90.4$ & -12.4 & $\$ 41.0$ & -21.9 \\
\hline 1999 & $\$ 1,091.4$ & $\$ 852.1$ & 67.5 & $\$ 12.7$ & 299.1 & $\$ 230.7$ & 21.8 & $\$ 112.0$ & 23.9 & $\$ 68.4$ & 66.8 \\
\hline 2000 & $\$ 1,400.5$ & $\$ 1,138.0$ & 33.5 & $\$ 8.3$ & -34.7 & $\$ 255.5$ & 10.7 & $\$ 144.2$ & 28.8 & $\$ 98.6$ & 44.1 \\
\hline 2001 & $\$ 827.6$ & $\$ 601.2$ & -47.2 & $\$ 6.2$ & -25.0 & $\$ 216.9$ & -15.1 & $\$ 108.7$ & -24.6 & $\$ 54.3$ & -45.0 \\
\hline 2002 & $\$ 628.0$ & $\$ 443.4$ & -26.2 & $\$ 9.2$ & 48.0 & $\$ 173.3$ & -20.1 & $\$ 95.7$ & -12.0 & $\$ 32.2$ & -40.6 \\
\hline 2003 & $\$ 587.0$ & $\$ 376.8$ & -15.0 & $\$ 6.3$ & -31.6 & $\$ 190.1$ & 9.7 & $\$ 110.8$ & 15.8 & $\$ 49.1$ & 52.2 \\
\hline 2004 & $\$ 744.3$ & $\$ 422.2$ & 12.0 & $\$ 7.8$ & 23.6 & $\$ 291.9$ & 53.5 & $\$ 156.7$ & 41.4 & $\$ 85.4$ & 74.0 \\
\hline 2005 & $\$ 980.7$ & $\$ 622.6$ & 47.5 & $\$ 2.8$ & -64.5 & $\$ 327.2$ & 12.1 & $\$ 173.9$ & 11.0 & $\$ 87.1$ & 2.0 \\
\hline 2006 & $\$ 1,463.4$ & $\$ 981.9$ & 57.7 & $-\$ 6.5$ & -334.4 & $\$ 427.2$ & 30.5 & $\$ 223.8$ & 28.7 & $\$ 123.2$ & 41.4 \\
\hline 2007 & $\$ 1,975.5$ & $\$ 1,310.4$ & 33.5 & $\$ 22.5$ & -446.6 & $\$ 574.3$ & 34.4 & $\$ 271.3$ & 21.2 & $\$ 153.1$ & 24.3 \\
\hline 2008 & $\$ 1,790.7$ & $\$ 1,019.6$ & -22.2 & $\$ 24.4$ & 8.3 & $\$ 650.0$ & 13.2 & $\$ 288.4$ & 6.3 & $\$ 127.2$ & -16.9 \\
\hline 2009 & $\$ 1,197.8$ & $\$ 606.2$ & -40.5 & $\$ 11.9$ & -51.1 & $\$ 519.2$ & -20.1 & $\$ 249.0$ & -13.7 & $\$ 111.6$ & -12.3 \\
\hline 2010 & $\$ 1,309.0$ & $\$ 618.6$ & 2.0 & $-\$ 1.3$ & -110.5 & $\$ 616.7$ & 18.8 & $\$ 325.9$ & 30.9 & $\$ 179.4$ & 60.8 \\
\hline 2011 & $\$ 1,524.4$ & $\$ 747.9$ & 20.9 & $-\$ 1.8$ & 40.5 & $\$ 684.4$ & 11.0 & $\$ 374.5$ & 14.9 & $\$ 211.5$ & 17.9 \\
\hline
\end{tabular}

(Source) UNCTAD Statistics (2012). 
Table 5. Annual FDI outflows

(in Billion US dollars, current rate)

\begin{tabular}{|c|c|c|c|c|c|c|c|c|c|c|c|}
\hline Year & World & $\begin{array}{l}\text { Developed } \\
\text { Economies }\end{array}$ & $\begin{array}{c}\% \\
\text { Growth }\end{array}$ & Japan & $\begin{array}{c}\% \\
\text { Growth }\end{array}$ & $\begin{array}{l}\text { Developing } \\
\text { economies }\end{array}$ & $\begin{array}{c}\% \\
\text { Growth }\end{array}$ & $\begin{array}{c}\text { East, } \\
\text { South \& } \\
\text { Southeast } \\
\text { Asia }\end{array}$ & $\begin{array}{c}\% \\
\text { Growth }\end{array}$ & $\begin{array}{c}\text { Southeast } \\
\text { \& East } \\
\text { Asia } \\
\text { Excl. } \\
\text { China }\end{array}$ & $\begin{array}{c}\% \\
\text { Growth }\end{array}$ \\
\hline 1980 & $\$ 51.6$ & $\$ 48.4$ & & $\$ 2.4$ & & $\$ 3.2$ & & $\$ 0.6$ & & $\$ 0.5$ & \\
\hline 1981 & $\$ 51.5$ & $\$ 49.9$ & 3.2 & $\$ 4.9$ & 105.2 & $\$ 1.6$ & -50.4 & $\$ 0.5$ & -16.6 & $\$ 0.5$ & -14.5 \\
\hline 1982 & $\$ 27.4$ & $\$ 24.8$ & -50.3 & $\$ 4.5$ & -7.2 & $\$ 2.6$ & 66.6 & $\$ 0.9$ & 94.8 & $\$ 0.9$ & 84.5 \\
\hline 1983 & $\$ 37.4$ & $\$ 35.4$ & 42.6 & $\$ 3.6$ & -20.4 & $\$ 2.0$ & -23.5 & $\$ 1.1$ & 24.0 & $\$ 1.0$ & 18.8 \\
\hline 1984 & $\$ 50.1$ & $\$ 47.7$ & 35.0 & $\$ 6.0$ & 65.1 & $\$ 2.4$ & 18.8 & $\$ 1.7$ & 52.1 & $\$ 1.6$ & 53.9 \\
\hline 1985 & $\$ 62.0$ & $\$ 58.1$ & 21.6 & $\$ 6.4$ & 8.0 & $\$ 4.0$ & 65.0 & $\$ 2.8$ & 66.3 & $\$ 2.2$ & 38.4 \\
\hline 1986 & $\$ 96.8$ & $\$ 91.7$ & 57.9 & $\$ 14.4$ & 123.6 & $\$ 5.1$ & 29.4 & $\$ 3.6$ & 26.5 & $\$ 3.1$ & 42.6 \\
\hline 1987 & $\$ 142.0$ & $\$ 135.3$ & 47.6 & $\$ 20.1$ & 39.6 & $\$ 6.7$ & 31.2 & $\$ 4.7$ & 31.7 & $\$ 4.2$ & 35.0 \\
\hline 1988 & $\$ 182.5$ & $\$ 170.4$ & 26.0 & $\$ 35.4$ & 76.3 & $\$ 12.0$ & 79.0 & $\$ 8.6$ & 82.1 & $\$ 7.7$ & 83.8 \\
\hline 1989 & $\$ 234.1$ & $\$ 214.3$ & 25.7 & $\$ 46.3$ & 30.5 & $\$ 19.8$ & 64.2 & $\$ 12.3$ & 44.0 & $\$ 11.5$ & 50.3 \\
\hline 1990 & $\$ 241.5$ & $\$ 229.6$ & 7.1 & $\$ 50.8$ & 9.8 & $\$ 11.9$ & -39.7 & $\$ 11.9$ & -3.5 & $\$ 11.1$ & -4.1 \\
\hline 1991 & $\$ 198.0$ & $\$ 184.6$ & -19.6 & $\$ 31.6$ & -37.7 & $\$ 13.5$ & 13.1 & $\$ 8.2$ & -31.0 & $\$ 7.3$ & -34.1 \\
\hline 1992 & $\$ 202.6$ & $\$ 177.9$ & -3.6 & $\$ 17.3$ & -45.3 & $\$ 23.2$ & 71.8 & $\$ 17.9$ & 117.6 & $\$ 13.9$ & 89.9 \\
\hline 1993 & $\$ 242.6$ & $\$ 202.2$ & 13.6 & $\$ 13.9$ & -19.6 & $\$ 39.3$ & 69.8 & $\$ 30.3$ & 69.5 & $\$ 26.0$ & 87.5 \\
\hline 1994 & $\$ 286.9$ & $\$ 239.0$ & 18.2 & $\$ 18.1$ & 30.2 & $\$ 47.5$ & 20.9 & $\$ 39.7$ & 30.8 & $\$ 37.6$ & 44.6 \\
\hline 1995 & $\$ 363.2$ & $\$ 306.9$ & 28.4 & $\$ 22.6$ & 24.9 & $\$ 55.7$ & 17.2 & $\$ 45.9$ & 15.6 & $\$ 43.7$ & 16.4 \\
\hline 1996 & $\$ 397.8$ & $\$ 331.4$ & 8.0 & $\$ 23.4$ & 3.5 & $\$ 65.4$ & 17.4 & $\$ 52.4$ & 14.3 & $\$ 49.9$ & 14.1 \\
\hline 1997 & $\$ 477.5$ & $\$ 398.9$ & 20.4 & $\$ 26.0$ & 11.0 & $\$ 75.2$ & 15.0 & $\$ 52.8$ & 0.7 & $\$ 50.0$ & 0.2 \\
\hline 1998 & $\$ 689.7$ & $\$ 638.0$ & 60.0 & $\$ 24.2$ & -7.1 & $\$ 50.3$ & -33.1 & $\$ 31.6$ & -40.1 & $\$ 28.8$ & -42.4 \\
\hline 1999 & $\$ 1,088.1$ & $\$ 1,018.4$ & 59.6 & $\$ 22.7$ & -5.8 & $\$ 67.3$ & 33.9 & $\$ 38.9$ & 23.0 & $\$ 36.8$ & 27.7 \\
\hline 2000 & $\$ 1,226.6$ & $\$ 1,088.3$ & 6.9 & $\$ 31.6$ & 38.7 & $\$ 135.1$ & 100.6 & $\$ 80.8$ & 107.8 & $\$ 79.3$ & 115.7 \\
\hline 2001 & $\$ 747.7$ & $\$ 661.8$ & -39.2 & $\$ 38.3$ & 21.5 & $\$ 83.1$ & -38.5 & $\$ 47.9$ & -40.6 & $\$ 39.6$ & -50.0 \\
\hline 2002 & $\$ 528.5$ & $\$ 476.3$ & -28.0 & $\$ 32.3$ & -15.8 & $\$ 47.5$ & -42.9 & $\$ 31.8$ & -33.8 & $\$ 27.5$ & -30.7 \\
\hline 2003 & $\$ 570.7$ & $\$ 513.2$ & 7.7 & $\$ 28.8$ & -10.8 & $\$ 46.7$ & -1.7 & $\$ 25.2$ & -20.6 & $\$ 20.8$ & -24.3 \\
\hline 2004 & $\$ 925.7$ & $\$ 788.8$ & 53.7 & $\$ 30.9$ & 7.5 & $\$ 122.8$ & 163.1 & $\$ 83.4$ & 230.5 & $\$ 75.6$ & 263.6 \\
\hline 2005 & $\$ 888.6$ & $\$ 741.7$ & -6.0 & $\$ 45.8$ & 47.9 & $\$ 132.5$ & 7.9 & $\$ 74.0$ & -11.3 & $\$ 58.2$ & -23.0 \\
\hline 2006 & $\$ 1,415.1$ & $\$ 1,152.0$ & 55.3 & $\$ 50.3$ & 9.8 & $\$ 239.3$ & 80.6 & $\$ 128.8$ & 74.1 & $\$ 92.8$ & 59.6 \\
\hline 2007 & $\$ 2,198.0$ & $\$ 1,829.6$ & 58.8 & $\$ 73.5$ & 46.3 & $\$ 316.9$ & 32.4 & $\$ 194.1$ & 50.7 & $\$ 151.5$ & 63.2 \\
\hline 2008 & $\$ 1,969.3$ & $\$ 1,580.8$ & -13.6 & $\$ 128.0$ & 74.1 & $\$ 328.1$ & 3.6 & $\$ 185.2$ & -4.6 & $\$ 113.3$ & -25.2 \\
\hline 2009 & $\$ 1,175.1$ & $\$ 857.8$ & -45.7 & $\$ 74.7$ & -41.7 & $\$ 268.5$ & -18.2 & $\$ 193.0$ & 4.2 & $\$ 120.1$ & 6.0 \\
\hline 2010 & $\$ 1,451.4$ & $\$ 989.6$ & 15.4 & $\$ 56.3$ & -24.7 & $\$ 400.1$ & 49.0 & $\$ 256.6$ & 32.9 & $\$ 174.2$ & 45.0 \\
\hline 2011 & $\$ 1,694.4$ & $\$ 1,237.5$ & 25.1 & $\$ 114.4$ & 103.2 & $\$ 383.8$ & -4.1 & $\$ 255.1$ & -0.6 & $\$ 174.8$ & 0.3 \\
\hline
\end{tabular}

(Source) UNCTAD Statistics (2012). 
Table 6. Foreign Direct Investment flows in developed and developing economies

(as percentage of world flows)

\begin{tabular}{|c|c|c|c|c|}
\hline \multirow{2}{*}{ Year } & \multicolumn{2}{|c|}{ Developed Economies } & \multicolumn{2}{|c|}{ Developing Economies } \\
\hline & Inward & Outward & Inward & Outward \\
\hline 1980 & 86 & 94 & 14 & 6 \\
\hline 1981 & 65 & 97 & 35 & 3 \\
\hline 1982 & 55 & 90 & 45 & 10 \\
\hline 1983 & 65 & 95 & 35 & 5 \\
\hline 1984 & 69 & 95 & 31 & 5 \\
\hline 1985 & 75 & 94 & 25 & 6 \\
\hline 1986 & 82 & 95 & 18 & 5 \\
\hline 1987 & 84 & 95 & 16 & 5 \\
\hline 1988 & 81 & 93 & 19 & 7 \\
\hline 1989 & 84 & 92 & 16 & 8 \\
\hline 1990 & 83 & 95 & 17 & 5 \\
\hline 1991 & 74 & 93 & 26 & 7 \\
\hline 1992 & 67 & 88 & 32 & 11 \\
\hline 1993 & 64 & 83 & 34 & 16 \\
\hline 1994 & 59 & 83 & 40 & 17 \\
\hline 1995 & 65 & 84 & 34 & 15 \\
\hline 1996 & 60 & 83 & 38 & 16 \\
\hline 1997 & 58 & 84 & 39 & 16 \\
\hline 1998 & 72 & 93 & 27 & 7 \\
\hline 1999 & 78 & 94 & 21 & 6 \\
\hline 2000 & 81 & 89 & 18 & 11 \\
\hline 2001 & 73 & 89 & 26 & 11 \\
\hline 2002 & 71 & 90 & 28 & 9 \\
\hline 2003 & 64 & 90 & 32 & 8 \\
\hline 2004 & 57 & 85 & 39 & 13 \\
\hline 2005 & 63 & 83 & 33 & 15 \\
\hline 2006 & 67 & 81 & 29 & 17 \\
\hline 2007 & 66 & 83 & 29 & 14 \\
\hline 2008 & 57 & 80 & 36 & 17 \\
\hline 2009 & 51 & 73 & 43 & 23 \\
\hline 2010 & 47 & 68 & 47 & 28 \\
\hline 2011 & 49 & 73 & 45 & 23 \\
\hline
\end{tabular}

(Source) UNCTAD Statistics (2012). 
Table 7. Foreign Direct Investment flows in developed and developing economies

(as percentage of Gross Domestic Product)

\begin{tabular}{|c|c|c|c|c|}
\hline \multirow{2}{*}{ Year } & \multicolumn{2}{|c|}{ Developed economies } & \multicolumn{2}{|c|}{ Developing economies } \\
\hline & Inward & Outward & Inward & Outward \\
\hline 1980 & 0.6 & 0.6 & 0.3 & 0.1 \\
\hline 1981 & 0.6 & 0.6 & 0.9 & 0.1 \\
\hline 1982 & 0.4 & 0.3 & 1.0 & 0.1 \\
\hline 1983 & 0.4 & 0.4 & 0.7 & 0.1 \\
\hline 1984 & 0.4 & 0.5 & 0.7 & 0.1 \\
\hline 1985 & 0.4 & 0.6 & 0.5 & 0.2 \\
\hline 1986 & 0.6 & 0.8 & 0.6 & 0.2 \\
\hline 1987 & 0.9 & 1.0 & 0.8 & 0.2 \\
\hline 1988 & 0.9 & 1.1 & 0.9 & 0.4 \\
\hline 1989 & 1.1 & 1.4 & 0.9 & 0.6 \\
\hline 1990 & 1.0 & 1.3 & 0.9 & 0.3 \\
\hline 1991 & 0.6 & 1.0 & 1.0 & 0.3 \\
\hline 1992 & 0.6 & 0.9 & 1.2 & 0.5 \\
\hline 1993 & 0.7 & 1.0 & 1.6 & 0.8 \\
\hline 1994 & 0.7 & 1.1 & 2.0 & 0.9 \\
\hline 1995 & 0.9 & 1.3 & 2.0 & 0.9 \\
\hline 1996 & 1.0 & 1.4 & 2.3 & 1.0 \\
\hline 1997 & 1.2 & 1.7 & 2.8 & 1.1 \\
\hline 1998 & 2.2 & 2.7 & 3.0 & 0.8 \\
\hline 1999 & 3.5 & 4.1 & 3.6 & 1.0 \\
\hline 2000 & 4.6 & 4.4 & 3.6 & 1.9 \\
\hline 2001 & 2.4 & 2.7 & 3.1 & 1.2 \\
\hline 2002 & 1.7 & 1.8 & 2.4 & 0.7 \\
\hline 2003 & 1.3 & 1.8 & 2.4 & 0.6 \\
\hline 2004 & 1.3 & 2.4 & 3.2 & 1.3 \\
\hline 2005 & 1.8 & 2.2 & 3.0 & 1.2 \\
\hline 2006 & 2.8 & 3.2 & 3.4 & 1.9 \\
\hline 2007 & 3.4 & 4.7 & 3.8 & 2.1 \\
\hline 2008 & 2.5 & 3.8 & 3.7 & 1.9 \\
\hline 2009 & 1.6 & 2.2 & 3.0 & 1.6 \\
\hline 2010 & 1.5 & 2.4 & 3.0 & 2.0 \\
\hline 2011 & 1.7 & 2.9 & 2.9 & 1.6 \\
\hline
\end{tabular}

(Source) UNCTAD Statistics (2012). 


\section{Table 8. Individual country regressions}

\section{A. Part 1}

(1990 2011)

\begin{tabular}{|c|c|c|c|c|c|c|c|c|c|c|c|c|}
\hline \multicolumn{13}{|c|}{ Dependent Variable: Foreign Direct Investment Outflow } \\
\hline \multirow{2}{*}{ Regressor } & \multicolumn{4}{|c|}{ China } & \multicolumn{4}{|c|}{ India } & \multicolumn{4}{|c|}{ Indonesia } \\
\hline & (1) & (2) & (3) & (4) & (1) & (2) & (3) & (4) & (1) & (2) & (3) & (4) \\
\hline$G D P_{t}$ & & $\begin{array}{l}0.01 * * * \\
(0.001)\end{array}$ & $\begin{array}{c:}0.01 \\
(0.01)\end{array}$ & $\begin{array}{l}-0.04 \\
(0.01) \\
\end{array}$ & & & & $\begin{array}{l}-0.02^{* * * *} \\
(0.002)\end{array}$ & & & $\begin{array}{l}0.02 \\
0.02)\end{array}$ & $\begin{array}{l}0.03^{* *} \\
(0.01)\end{array}$ \\
\hline$G D P_{t-1}$ & & & & & & & $\begin{array}{l}-0.02 \\
(0.01)\end{array}$ & & & & & \\
\hline$F D I(\text { inflow })_{t}$ & & & & & $\begin{array}{c}0.50^{* * * *} \\
(0.03)\end{array}$ & & $\begin{array}{l}0.45^{* *} \\
0.11)\end{array}$ & $\begin{array}{l}* .54^{* * *} \\
(0.04)\end{array}$ & & $\begin{array}{l}0.34 * * * \\
(0.06)\end{array}$ & $\begin{array}{l}0.15 \\
0.09)\end{array}$ & \\
\hline$F D I(\text { inflow })_{t-2}$ & & & $\begin{array}{l}-0.07 \\
0.11)\end{array}$ & & & & & & & & & \\
\hline Saving $_{t}$ & & & $\begin{array}{l}0.015 \\
0.03)\end{array}$ & $\begin{array}{c}0.12 \\
(0.04)\end{array}$ & & & & $\begin{array}{l}0.07 * * * \\
(0.01)\end{array}$ & & & $\begin{array}{l}-0.07 \\
(0.03)\end{array}$ & $\begin{array}{c}-0.06^{* *} \\
(0.02)\end{array}$ \\
\hline Saving $_{t-1}$ & & & & & & $\begin{array}{l}0.05^{* * *} \\
(0.004)\end{array}$ & $\begin{array}{c}0.01 \\
0.05)\end{array}$ & & & & & \\
\hline Reserve $_{t}$ & & & & $\begin{array}{l}-0.02 \\
(0.02) \\
\end{array}$ & & & $\begin{array}{c}0.04 \\
0.02)\end{array}$ & & & & & $\begin{array}{c}-0.09^{* * * *} \\
(0.02)\end{array}$ \\
\hline Reserve $_{t-1}$ & $\begin{array}{l}0.02 * * * \\
(0.001)\end{array}$ & & $\begin{array}{l}0.07 \\
0.03)\end{array}$ & & & & & $\begin{array}{l}-0.09^{* * *} \\
(0.01)\end{array}$ & & & & \\
\hline Reserve $_{t-2}$ & & & & & & & & & & & $\begin{array}{l}-0.03 \\
0.04)\end{array}$ & \\
\hline Export $_{t}$ & & & & $\begin{array}{c}-0.02 \\
0.01) \\
\end{array}$ & & & $\begin{array}{c}0.02 \\
(0.03)\end{array}$ & $\begin{array}{l}0.05^{*} \\
(0.01)\end{array}$ & $\begin{array}{c}0.04 * * * \\
(0.01)\end{array}$ & & $\begin{array}{c}0.02 \\
(0.03)\end{array}$ & $\begin{array}{c}0.05 \\
(0.02)\end{array}$ \\
\hline Export $_{t-2}$ & & & $\begin{array}{l}-0.13 \\
(0.06)\end{array}$ & & & & & & & & & \\
\hline$a$ & & $\begin{array}{l}-8.0^{* *} \\
(2.15)\end{array}$ & & & & $\begin{array}{c}-4.16 * * * \\
(0.93)\end{array}$ & $\begin{array}{c}3.61 \\
(1.78)\end{array}$ & & $\begin{array}{c}-1.44^{*} \\
(0.5)\end{array}$ & & $\begin{array}{c:c}-.97 \\
0.53)\end{array}$ & \begin{tabular}{|c}
$-2.00^{* * *}$ \\
$(0.32)$
\end{tabular} \\
\hline
\end{tabular}

Summary Statistics and Joint Tests

\begin{tabular}{|l|c|c|c|c|c|c|c|c|c|c|c|c|}
\hline F-Statistics & & 141.89 & & & & 133.48 & 89.84 & & 38.34 & & 14.02 & 37.70 \\
\hline SER & 5.36 & 6.41 & 4.98 & 5.05 & 1.76 & 2.45 & 1.4 & 0.63 & 1.05 & 1.33 & 0.85 & 0.62 \\
\hline$\overline{\boldsymbol{R}}^{\mathbf{2}}$ & 0.92 & 0.88 & 0.93 & 0.92 & 0.93 & 0.88 & 0.96 & 0.99 & 0.65 & 0.44 & 0.78 & 0.88 \\
\hline $\begin{array}{l}\text { Number of } \\
\text { Observations }\end{array}$ & 20 & 21 & 19 & 21 & 21 & 20 & 20 & 20 & 21 & 21 & 19 & 21 \\
\hline
\end{tabular}

(Notes) (i) * denote statistically significant at $1 \%$,

(ii) $* *$ denote statistically significant at $5 \%$,

(iii) $* * *$ denote statistically significant at $10 \%$. 


\section{B. Part 2}

\begin{tabular}{|c|c|c|c|c|c|c|c|c|c|c|c|c|}
\hline \multicolumn{13}{|c|}{ Dependent Variable: Foreign Direct Investment Outflow } \\
\hline \multirow{2}{*}{ Regressor } & \multicolumn{4}{|c|}{ Malaysia } & \multicolumn{4}{|c|}{ Philippines } & \multicolumn{4}{|c|}{ Thailand } \\
\hline & (1) & (2) & (3) & (4) & (1) & (2) & (3) & (4) & (1) & (2) & (3) & (4) \\
\hline$G D P_{t}$ & $\begin{array}{c}0.08 * * * \\
(0.01)\end{array}$ & & $\begin{array}{l}-0.08 \\
(0.06)\end{array}$ & & & & & $\begin{array}{l}-0.01 \\
(0.01)\end{array}$ & & & $\begin{array}{l}-0.02 \\
(0.01)\end{array}$ & \\
\hline$G D P_{t-1}$ & & & & & & & & & & & & $\begin{array}{c}-0.03^{*} \\
(0.01)\end{array}$ \\
\hline$F D I(\text { inflow })_{t}$ & & & $\begin{array}{l}0.27 \\
(0.34)\end{array}$ & $\begin{array}{l}0.54^{*} \\
(0.17)\end{array}$ & $\begin{array}{c}0.30^{* *} \\
(0.09)\end{array}$ & & & $\begin{array}{l}0.36 \\
0.27)\end{array}$ & & & & \\
\hline$F D I(\text { inflow })_{t-2}$ & & & & & & & & & & & $\begin{array}{c}.09 \\
(.05)\end{array}$ & \\
\hline Saving $_{t}$ & & & $\begin{array}{l}0.16 \\
(0.22)\end{array}$ & & & & $\begin{array}{l}0.02^{*} \\
(0.01)\end{array}$ & $\begin{array}{l}0.004 \\
0.08)\end{array}$ & & & $\begin{array}{l}0.09 \\
(0.03)\end{array}$ & \\
\hline Saving $_{t-1}$ & & & & & & & & & & & & $\begin{array}{c}0.09 \\
(0.02)\end{array}$ \\
\hline Saving $_{t-2}$ & & & & & & & & & & & & \\
\hline Reserve $_{t}$ & & & & & & & & $\begin{array}{l}0.02 \\
(0.04)\end{array}$ & $\left\{\begin{array}{l}0.04 * * * \\
(0.002)\end{array}\right.$ & & $\begin{array}{c}0.03 \\
(0.01)\end{array}$ & $\begin{array}{l}0.04 * * * \\
(0.01)\end{array}$ \\
\hline Reserve $_{t-1}$ & & $\begin{array}{c}0.15^{* * * *} \\
(0.01)\end{array}$ & $\begin{array}{l}0.29 \\
(0.06)\end{array}$ & $\begin{array}{c}0.14 * * * \\
(0.01)\end{array}$ & & & & & & $\begin{array}{l}0.05^{* * * *} \\
(0.004)\end{array}$ & & \\
\hline Export $_{t}$ & & & $\begin{array}{l}-0.06 \\
(0.05)\end{array}$ & & & $\begin{array}{l}0.01 * \\
0.004)\end{array}$ & & $\begin{array}{l}0.001 \\
0.02)\end{array}$ & & & & \\
\hline Export $_{t-2}$ & & & & & & & & & & & $\begin{array}{l}.001 \\
.01\end{array}$ & \\
\hline$a$ & $\begin{array}{c}-6.19^{* * * *} \\
(0.87)\end{array}$ & $\begin{array}{c}-3.44 * * * \\
(0.71)\end{array}$ & & $\begin{array}{c}-5.03 * * * \\
(0.76)\end{array}$ & & & & & $\begin{array}{c}-0.79 * * * \\
(0.16)\end{array}$ & \begin{tabular}{|c}
$-1.04 * * *$ \\
$(0.21)$
\end{tabular} & $\begin{array}{l}-1.74^{*} \\
(0.45)\end{array}$ & \begin{tabular}{|c}
$-1.21^{* *}$ \\
$(0.33)$
\end{tabular} \\
\hline
\end{tabular}

Summary Statistics and Joint Tests

\begin{tabular}{|l|c|c|c|c|c|c|c|c|c|c|c|c|}
\hline F-Statistics & 141.14 & 131.38 & & 103.94 & & & & & 215.36 & 157.65 & & 147.54 \\
\hline SER & 1.71 & 1.75 & 2.16 & 1.42 & 0.68 & 0.70 & 0.70 & 0.74 & 0.46 & 0.52 & 0.34 & 1.68 \\
\hline$\overline{\boldsymbol{R}}^{2}$ & 0.88 & 0.87 & 0.80 & 0.92 & 0.19 & 0.13 & 0.13 & 0.03 & 0.92 & 0.89 & 0.96 & 0.96 \\
\hline $\begin{array}{l}\text { Number of } \\
\text { Observations }\end{array}$ & 21 & 20 & 20 & 20 & 21 & 21 & 21 & 21 & 21 & 20 & 19 & 20 \\
\hline
\end{tabular}

(Notes) (i) * denote statistically significant at 1\%,

(ii) $* *$ denote statistically significant at $5 \%$,

(iii) *** denote statistically significant at $10 \%$. 


\section{Part 3}

\begin{tabular}{|c|c|c|c|c|c|c|c|c|}
\hline \multicolumn{9}{|c|}{ Dependent Variable: Foreign Direct Investment Outflow } \\
\hline & \multicolumn{4}{|c|}{ Australia } & \multicolumn{4}{|c|}{ New Zealand } \\
\hline Regressor & (1) & (2) & (3) & (4) & (1) & (2) & (3) & (4) \\
\hline$G D P_{t}$ & & & $\begin{array}{c}-0.11 \\
(0.08)\end{array}$ & $\begin{array}{l}-0.05 \\
(0.03)\end{array}$ & & & $\begin{array}{c}0.05 \\
(0.03)\end{array}$ & \\
\hline FDI (inflow $)_{t}$ & $\begin{array}{c}0.67 * * * \\
(0.06)\end{array}$ & & $\begin{array}{c}0.68^{* * *} \\
(0.1)\end{array}$ & $\begin{array}{c}0.67^{* * *} \\
(0.09)\end{array}$ & & $\begin{array}{l}0.21 \\
(0.1)\end{array}$ & $\begin{array}{c}0.27 \\
(0.17)\end{array}$ & $\begin{array}{l}0.42 * \\
(0.13)\end{array}$ \\
\hline Saving $_{t}$ & & & $\begin{array}{c}0.27 \\
(0.51)\end{array}$ & & & & & $\begin{array}{c}.24 \\
(.11)\end{array}$ \\
\hline Saving $_{t-1}$ & & & & & & & $\begin{array}{l}-0.47 \\
(0.24)\end{array}$ & $\begin{array}{c}-0.66^{* *} \\
(0.17)\end{array}$ \\
\hline Saving $_{t-2}$ & & & & & & & & $\begin{array}{c}0.26 \\
(0.12)\end{array}$ \\
\hline Reserve $_{t}$ & & & & & $\begin{array}{c}0.04 \\
(0.03)\end{array}$ & & & \\
\hline Reserve $_{t-1}$ & & & & & & & $\begin{array}{c}0.17 \\
(0.15)\end{array}$ & $\begin{array}{c}0.18 \\
(0.08)\end{array}$ \\
\hline Reserve $_{t-2}$ & & & $\begin{array}{l}0.026 \\
(0.25)\end{array}$ & & & & & \\
\hline Export $_{t}$ & & $\begin{array}{c}0.09^{* * *} \\
(0.02)\end{array}$ & $\begin{array}{c}0.18 \\
(0.36)\end{array}$ & $\begin{array}{c}0.26 \\
(0.13)\end{array}$ & & & & \\
\hline Export $_{t-2}$ & & & & & & & $\begin{array}{c}-0.02 \\
(0.12)\end{array}$ & \\
\hline$a$ & & & $\begin{array}{c}6.89 \\
(8.43)\end{array}$ & & & & $\begin{array}{c}0.87 \\
(0.84)\end{array}$ & \\
\hline
\end{tabular}

Summary Statistics and Joint Tests

\begin{tabular}{|l|c|c|c|c|c|c|c|c|}
\hline F-Statistics & & & 14.59 & & & & 4.01 & \\
\hline SER & 6.09 & 11.78 & 6.56 & 5.76 & 1.28 & 1.21 & 0.96 & 0.87 \\
\hline$\overline{\boldsymbol{R}}^{\mathbf{2}}$ & 0.81 & 0.27 & 0.79 & 0.83 & 0.01 & 0.12 & 0.44 & 0.56 \\
\hline $\begin{array}{l}\text { Number of } \\
\text { Observations }\end{array}$ & 21 & 21 & 19 & 21 & 21 & 21 & 20 & 19 \\
\hline
\end{tabular}

(Notes) (i) * denote statistically significant at 1\%,

(ii) $* *$ denote statistically significant at $5 \%$,

(iii) $* * *$ denote statistically significant at $10 \%$. 
Table 9. Regressions for country groups

(1990 2011)

\begin{tabular}{|c|c|c|c|c|c|c|c|c|c|c|c|c|}
\hline \multicolumn{13}{|c|}{ Dependent Variable: Foreign Direct Investment Outflow } \\
\hline \multirow{2}{*}{ Regressor } & \multicolumn{4}{|c|}{ Developed Group } & \multicolumn{4}{|c|}{ Developing Group } & \multicolumn{4}{|c|}{ Whole Group } \\
\hline & (1) & (2) & (3) & (4) & (1) & (2) & (3) & (4) & (1) & (2) & (3) & (4) \\
\hline$G D P_{t}$ & & & & & & & & $\begin{array}{l}0.03 * * * \\
(0.003)\end{array}$ & \begin{tabular}{|c|}
$0.03 * * *$ \\
$(0.004)$
\end{tabular} & $\begin{array}{l}0.03^{* * *} \\
(0.004)\end{array}$ & & $\begin{array}{l}0.008 \\
(0.01)\end{array}$ \\
\hline Saving $_{t}$ & & & & & & & & & $\begin{array}{c}-0.108^{* * * *} \\
(0.02)\end{array}$ & & & \\
\hline Reserve $_{t}$ & & & & $\begin{array}{c}0.27 \\
(0.13)\end{array}$ & & & & $\begin{array}{c}-0.07^{* * *} \\
(0.01)\end{array}$ & $\begin{array}{c}0.070^{* * * *} \\
(0.01)\end{array}$ & & $\begin{array}{c}-0.089^{* * *} \\
(0.02)\end{array}$ & $\begin{array}{c}-0.104^{* * *} \\
(0.02)\end{array}$ \\
\hline FDI (inflow) & $\left(\begin{array}{c:c}0.66 * * * \\
(0.04)\end{array}\right.$ & & & $\begin{array}{c}0.73^{* * *} \\
(0.06)\end{array}$ & & & $\begin{array}{l}0.23^{* * * *} \\
(0.01)\end{array}$ & & $\begin{array}{c}0.356^{* * *} \\
(0.05)\end{array}$ & $\begin{array}{l}0.278 \\
0.05)\end{array}$ & $\begin{array}{c}0.453^{* * *} \\
(0.05)\end{array}$ & $\begin{array}{c}0.418^{* * *} \\
(0.05)\end{array}$ \\
\hline$G D P_{t-1}$ & & & & $\begin{array}{l}-0.04 \\
(0.02)\end{array}$ & & $\begin{array}{l}0.01 * * * \\
(0.001)\end{array}$ & & & & & & \\
\hline Saving $_{t-1}$ & & & $\begin{array}{l}0.08^{* * *} \\
(0.01)\end{array}$ & & & & & $\begin{array}{c}-0.03^{* * * *} \\
(0.01)\end{array}$ & & $\begin{array}{l}-0.095 \\
0.014)\end{array}$ & & \\
\hline Reserve $_{t-1}$ & & & & $\begin{array}{c}-0.52^{* * *} \\
(0.14)\end{array}$ & $\begin{array}{l}0.03 * * * \\
(0.001)\end{array}$ & & & $\begin{array}{c}0.12^{* * *} \\
(0.01)\end{array}$ & & $\begin{array}{l}0.069 \\
(0.01)\end{array}$ & $\begin{array}{c}0.128^{* * * *} \\
(0.03)\end{array}$ & $\begin{array}{c}0.120^{* * *} \\
(0.03)\end{array}$ \\
\hline$G D P_{t-2}$ & & & & & & & & & & & $\begin{array}{l}0.035^{* * *} \\
(0.004)\end{array}$ & $\begin{array}{c}0.008^{* *} \\
(0.01)\end{array}$ \\
\hline Saving $_{t-2}$ & & & & $\begin{array}{c}0.15 \\
(0.06)\end{array}$ & & & & & & & $\begin{array}{c}-0.149^{* * *} \\
(0.02)\end{array}$ & $\begin{array}{c}-0.149^{* * *} \\
(0.02)\end{array}$ \\
\hline Reserve $_{t-2}$ & & & & $\begin{array}{l}0.35 \\
(0.14)\end{array}$ & & & & & & & $\begin{array}{c}.086^{* *} \\
(.03)\end{array}$ & $\begin{array}{c}.108 * * * \\
(.03)\end{array}$ \\
\hline Export $_{t}$ & & $\begin{array}{r}0.08^{* * *} \\
(0.01)\end{array}$ & & & & & & & $\begin{array}{c}-0.03^{* * *} \\
(0.01)\end{array}$ & $\begin{array}{l}-0.034 \\
(0.008)\end{array}$ & $\begin{array}{c}-0.024^{* *} \\
(0.01)\end{array}$ & $\begin{array}{c}-0.017 \\
(0.01)\end{array}$ \\
\hline$a$ & & & & & & $\begin{array}{c}-1.81^{* * *} \\
(0.50)\end{array}$ & & & & & & $\begin{array}{l}-1.061 \\
(0.64)\end{array}$ \\
\hline
\end{tabular}

Summary Statistics and Joint Tests

\begin{tabular}{|l|c|c|c|c|c|c|c|c|c|c|c|c|c|}
\hline F-Statistics & & & & & & 437.667 & & & & & & 73.226 \\
\hline SER & 4.416 & 8.379 & 8.733 & 3.913 & 3.475 & 4.184 & 5.084 & 2.520 & 5.024 & 5.113 & 4.465 & 4.417 \\
\hline$\overline{\boldsymbol{R}}^{2}$ & 0.822 & 0.360 & 0.336 & 0.873 & 0.873 & 0.815 & 0.715 & 0.936 & 0.708 & 0.710 & 0.788 & 0.793 \\
\hline $\begin{array}{l}\text { Number of } \\
\text { Observations }\end{array}$ & 42 & 42 & 40 & 38 & 100 & 100 & 105 & 95 & 168 & 160 & 152 & 152 \\
\hline
\end{tabular}

(Notes) (i) * denote statistically significant at $1 \%$,

(ii) $* *$ denote statistically significant at $5 \%$,

(iii) $* * *$ denote statistically significant at $10 \%$. 